\title{
Limiting the level of tertiary amines on polyamines leads to biocompatible nucleic acid vectors
}

Margarida Isabel Simão Carlos $^{1}$, Kai Zheng ${ }^{1,2}$, Natalie Garrett ${ }^{3}$, Natrah Arifin ${ }^{1}$, David G. Workman ${ }^{1}$, Ilona Kubajewska', Abdulrahman A. Halwani ${ }^{1,4}$, Julian Moger ${ }^{3}$, Qi Zhang ${ }^{2}$, Andreas G. Schätzlein ${ }^{1,5}$ and ljeoma F. Uchegbu ${ }^{1,5^{*}}$

${ }^{1}$ School of Pharmacy, University College London, 29-39 Brunswick Square, London WC1N 1AX, UK

${ }^{2}$ School of Chemical Engineering and Environment, Beijing Institute of Technology, 5 South, Zhongguancun Street, Beijing, 100081, PR China

${ }^{3}$ School of Physics, University of Exeter, Stocker Road, Exeter, EX4 4QL, UK.

${ }^{4}$ School of Pharmacy, King Abdulaziz University, Abdullah Sulayman St, Jeddah, 80200, Saudi Arabia

${ }^{5}$ Nanomerics Ltd, Euro House, 1394 High Road, London N20 9YZ.

*To whom correspondence should be addressed.

E-mail: ijeoma.uchegbu@ucl.ac.uk

Tel: +44 2077535997

Fax: +44 2077535942 


\section{Abstract}

We have designed an efficient, synthetic nucleic acid vector, which is relatively non-toxic. [N(2-ethylamino)-6-O-glycolchitosan - EAGC] polymers were 10 - 50 fold less toxic than Lipofectamine 2000, able to complex DNA, mRNA and siRNA into positively charged (zeta potential $=+40-50 \mathrm{mV}), 50-450 \mathrm{~nm}$ nanoparticles. The level of tertiary amine N-2ethylamino substitution (DS tert ) was inversely proportional to the IC50 of the EAGC polymers in the A431 cell line: IC50 $=6.18 D S_{\text {tert }}{ }^{-0.9}, r^{2}=0.9991$. EAGC polyplexes were stable against a heparin challenge, able to protect the nucleic acids from nuclease degradation and achieve levels of transfection comparable to Lipofectamine 2000 formulations. The relative biocompatibility of the vector allowed 10 fold higher doses of DNA ( $1 \mu \mathrm{g}$ compared to $0.1 \mu \mathrm{g}$ per well with Lipofectamine 2000) and siRNA (10.7 $\mu \mathrm{g}$ per well vs $1.3 \mu \mathrm{g}$ with Lipofectamine 2000) to be applied to cells, when compared to Lipofectamine 2000. Finally intranasal application of EAGC - siRNA complexes resulted in siRNA transfer to the neurons of the olfactory bulb.

\section{Keywords}

Gene Therapy, Chitosan, N-(2-ethylamino)-6-O-glycolchitosan, Polymer, siRNA, DNA, mRNA, Nucleic acid delivery 


\section{Introduction}

Gene therapy involves the administration of exogenous, therapeutic nucleic acids to enable the treatment of a disease (Pushpendra et al., 2012). The delivery of nucleic acids is largely agreed to be the rate limiting step to the introduction of new gene therapies (Couzin-Frankel, 2009; Guo and Huang, 2012) and despite the enormous investment in the science of gene therapy, only two approved products are available - Gendicine (Peng, 2005) and Glybera (Miller, 2012); both of which utilise viral vectors. There are no approved gene or ribonucleic acid [RNA - small interfering RNA (siRNA) or messenger RNA (mRNA)] therapeutics facilitated by synthetic vectors, although some synthetic lipid (Hyde et al., 2000) and poly(ethylenimine) (Gofrit et al., 2014) vectors have been tested in humans. For genes or RNA to be effective they require to be delivered intact to the inside of cells (Liang and Lam, 2012) and specifically the cell nucleus in the case of DNA (Scholz and Wagner, 2012); avoiding blood components, immune defence mechanisms, and enzymatic degradation (Scholz and Wagner, 2012).

Cationic polymers, in which the polymers have multiple amine groups, have been used to deliver therapeutic nucleic acids, as they form nanoparticle electrostatic complexes with nucleic acids at physiological pH (Brownlie et al., 2004). However cationic polymers are cytotoxic to cells, e.g. with IC50 values of $0.0019-0.0036 \mathrm{mg} \mathrm{mL}^{-1}$ in the case of branched poly(ethylenimine) (PEI) (Brownlie et al., 2004; Cheng et al., 2006) and $0.074 \mathrm{mg} \mathrm{mL}^{-1}$ in the case of linear PEI (Kafil and Omidi, 2011). This poor biocompatibility is presumably one of the reasons why linear PEI, when trialed in humans, was applied directly into the bladder (Gofrit et al., 2014). This local administration is similar to the way that the viral gene therapy products are used, i.e. intratumourally in the case of Gendicine or intramuscular (30 - 70 individual injections) in the case of Glybera (Gaudet et al., 2010; Peng, 2005).

The ultimate aim of our work is to develop nucleic acid medicines, which are active against central nervous system (CNS) diseases. In order to overcome the limitations to delivery posed by the blood brain barrier (Lalatsa et al., 2011), the intranasal route has been advocated. This 
route is emerging as an important route for the delivery of macromolecules to the brain via the olfactory bulb (Chapman et al., 2013). Thus, despite studies reporting the intracranial delivery of PEI - gene complexes (Boussif et al., 1995), the cytotoxicity of cationic polymers such as PEI means that they are not suitable for therapeutics intended for nose to brain delivery and a different type of carrier is required; one that is less intrinsically toxic to the neuronal tissue. The development of such a carrier is our goal.

Chitosan and its derivatives have been used as nucleic acid delivery systems (Sato et al., 2001; Uchegbu et al., 2004). Chitosan, which is composed of glucosamine and Nacetylglucosamine monomers linked by $\beta(1,4)$-glycosidic bonds, is less cytotoxic when compared to delivery systems such as PEI (Kean and Thanou, 2010) (Alves and Mano, 2008). However, at physiological $\mathrm{pH}(\mathrm{pH}=7.4)$, chitosan based nucleic acid delivery systems are generally less efficient than the polyamine (Erbacher et al., 1998; Hoggard-Koping et al., 2001; Moreira et al., 2009) or cationic lipid (Leong et al., 1998) carriers.

The transfection efficiency of chitosan is dependent on the $\mathrm{pH}$ of the environment, as protonation of the primary amines must occur prior to complexation of chitosan with the phosphate groups of DNA. Chitosan (pKa of $6.2-6.5$ (Wang et al., 2006)) behaves as an acid at physiological pH , is insoluble and shows low transfection ability (Lavertu et al., 2006; Nimesh et al., 2010). As the level of acetylation increases chitosan's transfection efficacy decreases (Huang et al., 2005). This is not unexpected as acetylation decreases the aqueous solubility of chitosan. The molecular weight of chitosan is another characteristic of the polymer that appears to affect the transfection efficiency. Some reports claim that a molecular weight range of $100-400 \mathrm{kDa}$ (along with a low degree of acetylation) results in optimum transfection efficiency (Huang et al., 2005; Techaarpornkul et al., 2010), while other reports state that a molecular weight of less than $100 \mathrm{kDa}$ is optimum for nucleic acid transfer (Erbacher et al., 1998; Hoggard-Koping et al., 2001; Holzerny et al., 2012; Techaarpornkul et al., 2010; Uchegbu et al., 2004). 
Various derivatives of chitosan have been synthesized to address the low DNA binding capacity of chitosan at physiological $\mathrm{pH}$ and as such trimethyl quaternary ammonium (Thanou et al., 2002), histidine (Moreira et al., 2009), urocanic acid (Kim et al., 2003) and PEI (Tripathi et al., 2012) chitosan derivatives have been evaluated. While these strategies do increase the transfection efficiency of chitosan, some of these new nucleic acid carriers were shown to be relatively cytotoxic (e.g. IC50 $=0.09 \mathrm{mg} \mathrm{mL}^{-1}$ ) (Wong et al., 2006), or their ultimate in vitro gene transfer efficiency was still significantly inferior to the commercial transfection agent Lipofectamine (Kim et al., 2003).

To utilise the nose to brain route, it is important to prepare efficient nucleic acid vectors with low cell cytotoxicity as vectors. siRNA nose to brain delivery has been attempted with both naked siRNA (Renner et al., 2012) and with siRNA complexed with various carriers (Kim et al., 2012; Perez et al., 2012). While most of the carriers were not evaluated for their cytotoxicity, some of the carriers, which were tested for their cytotoxicity, were toxic to cells in vitro at a concentration of $0.08 \mathrm{mg} \mathrm{mL}^{-1}$.

In this work we have prepared various $\mathrm{N}$-(2-ethylamino)-6-O-glycolchitosan polymers. The ethylamine groups were added to enable the polymer to be protonated at physiological $\mathrm{pH}$ and bind to the anionic phosphate groups of DNA, siRNA and mRNA. We have ascertained the level of ethylamine substitution which provides good nucleic acid transfer as well as low cytotoxicity. The 6-O-glycol unit increases the water solubility of the polymer at physiological pH when compared to chitosan (Chooi et al., 2014; Uchegbu et al., 2014a); polymer water solubility will contribute to nucleic acid binding as insoluble material will not be available to bind the solution phase nucleic acids. In considering the design of our vector, we opted for a molecular weight of between $10-30 \mathrm{kDa}$, as previously chitosan $\mathrm{N}$-trimethyl derivatives were more active as gene transfer systems in this molecular weight range (Uchegbu et al., 2004). 


\section{Experimental Section}

\subsection{Materials}

All chemicals and reagents were supplied by Sigma Aldrich, Dorset, UK, unless otherwise specified. Organic solvents were supplied by Fischer Scientific, Dorset, UK and Visking seamless cellulose dialysis membranes were obtained from Medicell International Ltd., London, UK. All chemicals and reagents were used without further purification. Tissue culture reagents were obtained from Invitrogen, Paisley, UK.

\subsection{Synthesis and Characterisation of $\mathrm{N}$-(2-ethylamino)-6-0-glycolchitosan}

Glycol chitosan (GC) was degraded in hydrochloric acid $(\mathrm{HCl})$ as previously described (Siew et al., 2012). Briefly (GC, 1g, 4.9 mmoles of monomer) was dissolved in hydrochloric acid $(4 \mathrm{M}, 76 \mathrm{~mL})$ and placed for 4 hours in a preheated water bath at $50^{\circ} \mathrm{C}$. The product resulting from the acid degradation (GC28) was purified by dialysis (Visking seamless cellulose tubing, molecular weight cut off $7000 \mathrm{Da}$ ) against deionised water (5L) with six changes over 24 hours. The dialysed solution was freeze-dried and purified GC28 was recovered as a cream coloured cotton wool like material: Yield $=0.5 \mathrm{~g}, \mathrm{Mw}=28,480 \mathrm{Da}, \mathrm{Mn}=27,750, \mathrm{Mw} / \mathrm{Mn}=1.026, \mathrm{dn} / \mathrm{dc}$ $=0.149,{ }^{1} \mathrm{H}$ NMR: $\delta_{1.9}=\boldsymbol{C H}_{3} \mathrm{CO}-$ (acetyl-glycol chitosan), $\delta_{3.0}=-\mathbf{C H}-\mathrm{NH}_{2}$ (C2 glycol chitosan), $\delta_{3.4-4.1}=-\mathbf{C H}-\mathrm{O}-$ and $-\mathrm{CH}_{2}-\mathrm{OH}$ (glycol chitosan), $\delta_{4.5}=-\mathbf{C H}-\mathrm{O}-(\mathrm{C} 1$ glycol chitosan).

GC25 and GC24 were synthesised in a similar manner to GC28 except that the GC, HCL ratio was increased. (GC, $2.00 \mathrm{~g}, 9.8$ mmoles of monomer) was dissolved in hydrochloric acid (4 $\mathrm{M}, 38 \mathrm{~mL}$ ) and placed for 4 hours and 5 hours respectively in a preheated water bath at $50{ }^{\circ} \mathrm{C}$ to get GC25 and GC24. The products resulting from the acid degradation (GC25 and GC24) were purified by dialysis (Visking seamless cellulose tubing, molecular weight cut off 3,500 Da) against deionised water $(5 \mathrm{~L})$ with six changes over 24 hours. The dialysed solutions were freeze-dried and low molecular weight GC (GC25 and GC24) were recovered as a cream coloured cotton wool like material 
GC25: Yield $=1.63 \mathrm{~g}(82 \%) . \mathrm{Mw}=25,760, \mathrm{Mn}=25,620, \mathrm{Mw} / \mathrm{Mn}=1.005, \mathrm{dn} / \mathrm{dc}=0.1459$ ${ }^{1} \mathrm{H}$ NMR: $\delta 2.1=\mathrm{CH}_{3}$-CO- (acetyl-glycol chitosan), $\delta 3.1-3.3=-\mathbf{C H}-\mathrm{N}$ (C2 glycol chitosan), $\delta 3.4-$ $4.4=-\mathrm{CH}-\mathrm{O}-$ and $-\mathrm{CH}_{2}-\mathrm{OH}$ (glycol chitosan), $\delta 4.9=-\mathbf{C H}-\mathrm{O}-(\mathrm{C} 1$ glycol chitosan)

GC24: Yield $=1.44 \mathrm{~g}(72 \%) . \mathrm{Mw}=24,450, \mathrm{Mn}=24,310, \mathrm{Mw} / \mathrm{Mn}=1.006, \mathrm{dn} / \mathrm{dc}=0.1484$ ${ }^{1} \mathrm{H}$ NMR: $\delta_{2.1}=\mathrm{CH}_{3}$-CO- (acetyl-glycol chitosan), $\delta_{3.1-3.3}=-\mathbf{C H}-\mathrm{N}\left(\mathrm{C} 2\right.$ glycol chitosan), $\delta_{3.5-4.2}=$ - $\mathrm{CH}-\mathrm{O}-$ and $-\mathrm{CH}_{2}-\mathrm{OH}$ (glycol chitosan), $\delta_{4.9}=-\mathbf{C H}-\mathrm{O}-(\mathrm{C} 1$ glycol chitosan).

A further batch of $\mathrm{GC}$ (GC17) with an even lower molecular weight was synthesised in a similar manner to GC28 except that the incubation in $\mathrm{HCL}$ was carried out for 8 hours: Yield $=0.5 \mathrm{~g}$. $\mathrm{Mw}=17,430, \mathrm{Mn}=17,330, \mathrm{Mw} / \mathrm{Mn}=1.006, \mathrm{dn} / \mathrm{dc}=0.144,{ }^{1} \mathrm{H}$ NMR: $\delta_{1.9}=\mathrm{CH}_{3} \mathrm{CH}-($ acetylglycol chitosan), $\delta_{3.0}=-\mathbf{C H}-\mathrm{NH}_{2}$ (C2 glycol chitosan), $\delta_{3.4-4.1}=-\mathbf{C H}-\mathrm{O}-$ and $-\mathbf{C H}_{2}-\mathrm{OH}$ (glycol chitosan), $\delta_{4.5}=-\mathbf{C H}-\mathrm{O}-(\mathrm{C} 1$ glycol chitosan).

The degraded GC (GC28, $100 \mathrm{mg}, 0.49$ mmoles of monomer) was dissolved in a solution of $\mathrm{N}$-methyl-2-pyrrolidone (NMP) (20 mL) containing triethylamine $(500 \mu \mathrm{L}, 3.59 \mathrm{mmoles})$. The solution was allowed to stir for $1 \mathrm{~h}$ at $40^{\circ} \mathrm{C}$ in an oil bath until the GC was completely dissolved. To this dissolved GC was added 2-tertbutoxycarbonylamino-ethyl bromide (1000 mg, 4.46 mmoles) such that the molar ratio between GC monomer and 2-tertbutoxycarbonylamino-ethyl bromide was $1: 10$. The reaction was left to stir for $24 \mathrm{~h}$, at $40^{\circ} \mathrm{C}$. Finally the solution was mixed with water $(40 \mathrm{~mL})$ and washed with diethyl ether $(3 \times 50 \mathrm{~mL})$ to remove the unreacted 2tertbutoxycarbonylamino-ethyl bromide. The aqueous phase was collected and dialyzed, as previously described, against deionised water $(5 \mathrm{~L})$ with six changes over 24 hours. The final polymer solution was freeze-dried. The recovered polymer was dissolved in $\mathrm{HCL}(50 \mathrm{ml}, 4 \mathrm{M})$ and stirred for 3 hours at room temperature in order to cleave the tertbutoxycarbonyl group. This solution was dialyzed as previously described and freeze dried to give $\mathrm{N}$-(2-ethylamino)6-O-glycol chitosan (EAGC29) which presented as a cream coloured solid. Yield $=0.06 \mathrm{~g}$ (60\%). $M w=29,850 \mathrm{Da}, \mathrm{Mn}=28,290 \mathrm{Da}, \mathrm{Mw} / \mathrm{Mn}=1.055, \mathrm{dn} / \mathrm{dc}=0.1544 .{ }^{1} \mathrm{H}$ NMR: $\delta_{2.0}=$ $\boldsymbol{C H}_{3}$-CO- (acetyl-glycol chitosan), $\delta_{2.5}=-\boldsymbol{C H}-\mathrm{N}\left(\mathrm{CH}_{2} \mathrm{CH}_{2} \mathrm{NH}_{2}\right)_{2}$ (C2 diethylamino-substituted 
glycol chitosan), $\delta_{2.7}=-\boldsymbol{C H}-\mathrm{NHCH}_{2} \mathrm{CH}_{2} \mathrm{NH}_{2}$ (C2 monoethylamino substituted glycol chitosan), $\delta_{2.9-3.1}=-\mathrm{CH}-\mathrm{NH}_{2} \quad\left(\mathrm{C} 2\right.$ glycol chitosan), $-\mathrm{CH}-\mathrm{N}\left(\mathrm{CH}_{2} \mathrm{CH}_{2} \mathrm{NH}_{2}\right)_{2}$ (diethylamino), $-\mathrm{CH}-$ $\mathrm{NHCH}{ }_{2} \mathrm{CH}_{2} \mathrm{NH}_{2}$ (monoethylamino), $\delta_{3.5-4.1}=-\mathbf{C H}-\mathrm{O}$ - and $-\mathrm{CH}_{2}-\mathrm{OH}$ (glycol chitosan), $\delta_{4.7}=-\mathbf{C H}-$ O- (C1 glycol chitosan).

EAGC21 and EAGC17 were synthesised in a similar manner from GC17 in which GC17 (100 $\mathrm{mg}, 0.49$ mmoles of monomer) was reacted with either $500 \mathrm{mg}(2.23$ mmoles $)$ or $200 \mathrm{mg}(0.89$ mmoles) of 2-tertbutoxycarbonylamino-ethyl bromide at $40^{\circ} \mathrm{C}$ to give EAGC21 and EAGC17 respectively, which both presented as cream coloured cotton wool like materials. EAGC22 was synthesised from GC24 by reacting GC24 (200 mg, 0.82 mmoles) with $8 \mathrm{~g}$ (35.68 mmoles) of 2-tertbutoxycarbonylamino-ethyl bromide in a similar manner.

EAGC11 was synthesised from GC25 by reacting GC25 (226 mg, 0.93 mmoles) with $2.086 \mathrm{~g}$ (8.8 mmoles) of 2-tertbutoxycarbonylamino-ethyl bromide in a similar manner, but with the reaction carried out at room temperature.

EAGC22: Yield $=0.18 \mathrm{~g}(63 \%) . \mathrm{Mw}=25,500 \mathrm{Da}, \mathrm{Mn}=24,230 \mathrm{Da}, \mathrm{Mw} / \mathrm{Mn}=1.052, \mathrm{dn} / \mathrm{dc}=$ 0.1510. ${ }^{1} \mathrm{H}$ NMR: $\delta_{2.1}=\boldsymbol{C H}_{3} \mathrm{CO}-$ (acetyl-glycol chitosan), $\delta_{2.5}=-\boldsymbol{C H}-\mathrm{NH}\left(\mathrm{CH}_{2} \mathrm{CH}_{2} \mathrm{NH}_{2}\right)_{2}(\mathrm{C} 2$ diethylamino substituted glycol chitosan), $\delta_{3-3.1}=-\mathbf{C H}-\mathrm{NH}_{2}$ (C2 glycol chitosan), $\delta_{3.1-3.2}=-\mathrm{CH}-$ $\mathrm{NH}\left(\mathrm{CH}_{2} \boldsymbol{C H}_{2} \mathrm{NH}_{2}\right)_{2}$ (diethylamino), $\delta_{3.5-4.1}=-\boldsymbol{C H}-\mathrm{O}$ - and $-\boldsymbol{C H}_{2}-\mathrm{OH}$ (glycol chitosan), $\delta_{4.9}=-\mathbf{C H}-$ O- (C1 glycol chitosan).

EAGC21: Yield $=0.06 \mathrm{~g}(60 \%) . \mathrm{Mw}=17,620 \mathrm{Da}, \mathrm{Mn}=17,340 \mathrm{Da}, \mathrm{Mw} / \mathrm{Mn}=1.016, \mathrm{dn} / \mathrm{dc}=$ 0.1642. ${ }^{1} \mathrm{H}$ NMR: $\delta_{2.0}=\boldsymbol{C H}_{3}$-CO- (acetyl-glycol chitosan), $\delta_{2.5}=-\boldsymbol{C H}-\mathrm{N}\left(\mathrm{CH}_{2} \mathrm{CH}_{2} \mathrm{NH}_{2}\right)_{2}(\mathrm{C} 2$ diethylamino-substituted glycol chitosan), $\delta_{2.7}=-\mathbf{C H}-\mathrm{NHCH}_{2} \mathrm{CH}_{2} \mathrm{NH}_{2}$ (C2 monoethylamino substituted glycol chitosan), $\delta_{2.9-3.1}=-\mathbf{C H}-\mathrm{NH}_{2}$ (C2 glycol chitosan), $-\mathrm{CH}-\mathrm{N}\left(\mathbf{C H}_{2} \mathbf{C H}_{2} \mathrm{NH}_{2}\right)_{2}$ (diethylamino), $-\mathrm{CH}-\mathrm{NH} \mathrm{CH}_{2} \mathrm{CH}_{2} \mathrm{NH}_{2}$ (monoethylamino), $\delta_{3.5-4.1}=-\mathbf{C H}-\mathrm{O}-$ and $-\mathrm{CH}_{2}-\mathrm{OH}$ (glycol chitosan), $\delta_{4.7}=-\mathbf{C H}-\mathrm{O}-(\mathrm{C} 1$ glycol chitosan). 
EAGC17: Yield $=0.065 \mathrm{~g}(60 \%) . \mathrm{Mw}=16,910 \mathrm{Da}, \mathrm{Mn}=16,710 \mathrm{Da}, \mathrm{Mw} / \mathrm{Mn}=1.011, \mathrm{dn} / \mathrm{dc}=$

0.1565. ${ }^{1} \mathrm{H}$ NMR: $\delta_{2.0}=\boldsymbol{C H}_{3}$-CO- (acetyl-glycol chitosan), $\delta_{2.5}=-\boldsymbol{C H}-\mathrm{N}\left(\mathrm{CH}_{2} \mathrm{CH}_{2} \mathrm{NH}_{2}\right)_{2}(\mathrm{C} 2$ diethylamino-substituted glycol chitosan), $\delta_{2.7}=-\mathbf{C H}-\mathrm{NHCH}_{2} \mathrm{CH}_{2} \mathrm{NH}_{2}$ (C2 monoethylamino substituted glycol chitosan), $\delta_{2.9-3.1}=-\mathbf{C H}-\mathrm{NH}_{2}$ (C2 glycol chitosan), $-\mathrm{CH}-\mathrm{N}\left(\boldsymbol{C H}_{2} \mathbf{C H}_{2} \mathrm{NH}_{2}\right)_{2}$ (diethylamino), $-\mathrm{CH}-\mathrm{NHCH}_{2} \mathrm{CH}_{2} \mathrm{NH}_{2}$ (monoethylamino), $\delta_{3.5-4.1}=-\mathbf{C H}-\mathrm{O}-$ and $-\mathrm{CH}_{2}-\mathrm{OH}$ (glycol chitosan), $\delta_{4.7}=\mathbf{-} \mathbf{C H}-\mathrm{O}-(\mathrm{C} 1$ glycol chitosan).

EAGC11: Yield $=0.127 \mathrm{~g}(56 \%) . \mathrm{Mw}=26,180 \mathrm{Da}, \mathrm{Mn}=25,560 \mathrm{Da}, \mathrm{Mw} / \mathrm{Mn}=1.024, \mathrm{dn} / \mathrm{dc}=$ 0.146. ${ }^{1} \mathrm{H}$ NMR: $\delta_{2.1}=\boldsymbol{C H}_{3}$-CO- (acetyl-glycol chitosan), $\delta_{3.0}=-\boldsymbol{C H}-\mathrm{N}\left(\mathrm{CH}_{2} \mathrm{CH}_{2} \mathrm{NH}_{2}\right)_{2}(\mathrm{C} 2$ monoethylamino substituted glycol chitosan), $\delta_{3.1-3.4}=-\mathbf{C H}-\mathrm{NH}_{2}$ (C2 glycol chitosan), $-\mathrm{CH}-$ $\mathrm{NH} \mathrm{CH}_{2} \mathrm{CH}_{2} \mathrm{NH}_{2}$ (monoethylamino), $\delta_{3.4-4.3}=-\mathbf{C H}-\mathrm{O}$ - and $-\mathrm{CH}_{2}-\mathrm{OH}$ (glycol chitosan), $\delta_{4.9}=-\mathbf{C H}-$ O- (C1 glycol chitosan).

\subsubsection{Gel Permeation Chromatography - Multi-angle Laser Light Scattering (GPC- MALLS)}

The molecular weight of the GC and EAGC polymers were determined by GPC-MALLS. Filtered samples $\left(5 \mathrm{mg} \mathrm{mL}^{-1}\right)$ were injected onto a POLYSEP-GFC-P guard column $(35 \times 7.8$ mm, Phenomenex, UK) attached to a POLYSEP-GFC-P 4000 column using an Agilent 1200 Series autosampler (Agilent Technologies, Stockport, UK) connected to a DAWN® EOS® Multi-angle light scattering detector, Optilab rEX Interferometric Refractometer $(\lambda=690 \mathrm{~nm})$ and quasielastic light scattering detector (Wyatt Technology Corporation, Santa Barbara, USA) and eluted with a sodium acetate buffer (0.5 $\mathrm{M} \mathrm{CH}_{3} \mathrm{COONa}$ (anhydrous) / $0.2 \mathrm{M}$ $\mathrm{CH}_{3} \mathrm{COOH}, \mathrm{pH}$ 4.5) mobile phase. The measurements were performed at room temperature with a mobile phase flow rate of $0.7 \mathrm{~mL} \mathrm{~min}^{-1}$. The data were processed using ASTRA for Windows version 5 software (Wyatt Technology Corporation, USA).

The specific refractive index increment $(\mathrm{dn} / \mathrm{dc})$ of the $\mathrm{GC}$ and $\mathrm{EAGC}$ polymers were measured in sodium acetate buffer with an Optilab rEX Interferometric Refractometer. Filtered samples $(0.2 \mu \mathrm{m}, 33 \mathrm{~mm}$ Millex MP syringe driven filter unit, polyethersulfone (PES) membrane for 
sterilization of aqueous solutions) of 6 different concentrations ranging from $0.1-0.6 \mathrm{mg} \mathrm{mL}^{-1}$ were manually injected using an injection system (Wyatt Technology Corporation, USA) at a pump flow rate of $0.3 \mathrm{~mL} \mathrm{~min}^{-1}$. The data were processed using Wyatt ASTRA for Windows version 5 software.

\subsubsection{Nuclear Magnetic Resonance (NMR) Spectroscopy}

${ }^{1} \mathrm{H}$ NMR, was performed on GC and EAGC (both at $25 \mathrm{mg} \mathrm{mL}^{-1}$ ) in Deuterium Oxide $\left(\mathrm{D}_{2} \mathrm{O}\right)$ on a Bruker AMX $500 \mathrm{MHz}$ spectrometer (Bruker Instruments, Coventry, UK). The level of ethylamine substitution was determined by comparing the ratio of the di and monoethylamino substituted glycol chitosan ( $\delta=2.5$ and 2.7 respectively) with the sugar methine and methylene protons $(\delta=3.5-4.1)$.

\subsubsection{Titration}

GC and EAGC hydrochloride salts [prepared by adjusting the $\mathrm{pH}$ of the initial solutions in water to $\mathrm{pH}=2$ with $\mathrm{HCL}(0.1 \mathrm{M})$ ] at a concentration of $2 \mathrm{mg} \mathrm{mL}^{-1}$ were titrated with $\mathrm{NaOH}(0.05 \mathrm{M})$. Under continuous stirring, the titrant was added drop wise. During the titration, the volume of $\mathrm{NaOH}$ added and $\mathrm{pH}$ values of polymer solutions were recorded using a MPT-2 Autotitrator, (Malvern Instruments, Malvern, UK).

The buffer capacity $(\mathrm{C})$ is defined as the percentage of amino groups that become protonated in the $\mathrm{pH}$ range 5.1 to 7.4 , and may be calculated using equation 1 :

$\mathrm{C}=100 \frac{\mathrm{VM}}{\mathrm{N}}$ 1

where $\mathrm{V}=$ volume of sodium hydroxide used to raise the $\mathrm{pH}$ to $7.4, \mathrm{M}=$ number of moles of sodium hydroxide per $\mathrm{L}, \mathrm{N}=$ number of protonable nitrogen atoms contained in the known amount of EAGC or GC being titrated (Lin et al., 2008). 


\subsection{Characterization of EAGC - Nucleic Acid Nanoparticles}

\subsubsection{Nanoparticles Preparation}

DNA complexes were prepared at a final DNA concentration of $0.1 \mathrm{mg} \mathrm{mL}^{-1}$. Each polymer stock solution (EAGC17, EAGC21 and EAGC29) was prepared in sterile dextrose (5\% w/v), which had been filtered with a $0.22 \mu \mathrm{m}$ Millex filter. To the dextrose solution was added equal volumes of the DNA ( $\beta$-galactosidase reporter plasmid, 4.7 kilo base pairs, Invitrogen, Paisley, UK, propagated in E. Coli) stock solution (in MiliQ water) to give polymer, DNA weight ratios of 1-60. The complexes were allowed to incubate at room temperature for 30 minutes or 1 hour before use.

siRNA complexes were prepared at a final siRNA concentration of $0.1 \mathrm{mg} \mathrm{mL}^{-1}$. The polymer stock solution (EAGC29) was prepared in sterile dextrose $(5 \%(\mathrm{w} / \mathrm{v})$ which had been filtered with a $0.22 \mu \mathrm{m}$ Millex filter. To the dextrose solution was added equal volumes of the siRNA (anti-ITCH siRNA, 19 base pairs, Eurofins Genomics, Ebersberg, Germany) stock solution (in insiMAX universal buffer, Eurofins mwg/ operon, London, UK) to give polymer, siRNA weight ratios of 1: 1 to $60: 1$. The complexes were allowed to incubate at room temperature for 30 minutes or 1 hour before use.

mRNA complexes were prepared at a final mRNA concentration of $0.01 \mathrm{mg} \mathrm{mL}^{-1}$. The polymer stock solution (EAGC11) was prepared in nuclease-free phosphate buffer $(\mathrm{pH}=6.0)$. Equal volumes of the mRNA ( $\beta$-galactosidase reporter mRNA, 5meC, $\Psi, 3,420$ nucleotides, Trilink, San Diego, USA) stock solution and polymer solution were combined to make final polyplexes at polymer, mRNA weight ratios of 50: 1, 60:1 and 70: 1. The complexes were allowed to incubate at room temperature for 1 hour before use. mRNA - EAGC22 complexes were prepared as detailed below.

\subsubsection{Agarose gel retardation assay}

An agarose gel solution $(1 \% \mathrm{w} / \mathrm{w})$ in Tris Acetate ethylene diamine tetraacetic acid (TAE) buffer [Tris $(40 \mathrm{mM})$, acetic acid $(20 \mathrm{mM})$, Ethylene diamine tetraacetic acid $(1 \mathrm{mM}), \mathrm{pH}=8]$ 
was heated in a microwave oven and stained with ethidium bromide $(0.3 \mu \mathrm{g} \mathrm{mL}-1)$. After cooling, the solution was left to solidify at room temperature in the casting tray containing a sample comb. The comb was then removed and the solidified gel tray was inserted into the electrophoresis chamber covered with TAE buffer. Complex samples (containing $0.1 \mathrm{mg} \mathrm{mL}^{-1}$ DNA or siRNA, or $0.01 \mathrm{mg} \mathrm{mL}^{-1} \mathrm{mRNA}, 10 \mu \mathrm{L}$ ) prepared as previously described, and incubated for 30 min or 1 hour, or naked DNA, siRNA $\left(0.1 \mathrm{mg} \mathrm{mL}^{-1}, 10 \mu \mathrm{L}\right)$ and mRNA $(0.01$ $\left.\mathrm{mg} \mathrm{mL}^{-1}, 10 \mu \mathrm{L}\right)$ controls, mixed with loading buffer $(2 \mu \mathrm{L}$, Thermo Fisher Scientific, Waltham, USA) were pipetted $(12 \mu \mathrm{L})$ into the sample wells with the end of the lane towards the cathode. The power supply (PowerPac ${ }^{\mathrm{TM}}$, Bio Rad, Hemel, UK) was connected to the chamber and power applied for $1 \mathrm{~h}$ at $60 \mathrm{~V}$ or $30 \mathrm{~min}$. at $100 \mathrm{~V}$ for mRNA. The results were imaged on a UV Transilluminator (ChemiDoc ${ }^{\mathrm{TM}}$ MP System, Bio Rad, Hemel, UK) to visualise the ethidium bromide-stained DNA, mRNA or siRNA in the gels.

\subsubsection{Transmission Electron Microscopy (TEM)}

One drop of the EAGC - nucleic acid complexes (siRNA or DNA complexes prepared as previously described and incubated for $1 \mathrm{~h}$ ) was placed onto a carbon/ Formvar coated 200 mesh copper grid (Agar Scientific, Stansted, UK) and negatively stained with uranyl acetate solution $(1 \% \mathrm{w} / \mathrm{v})$. Polymer and naked nucleic acid solutions were imaged as negative controls. Imaging was carried out with a Philips CM120 Biotwin Transmission Electron Microscope (Philips, Eindhoven, The Netherlands). Digital images were captured using a 5MP AMT camera (Deben UK Ltd, Suffolk, UK).

\subsubsection{Size and Zeta Potential}

The size of the complexes was determined by nanoparticle tracking analysis (NanoSight LM20, NanoSight Limited, Malvern, UK). The samples were prepared as previously described and allowed to incubate at room temperature for $1 \mathrm{~h}$. A volume of the sample $(0.2 \mathrm{~mL})$ was injected into the sample chamber. Videos of 30 s in length were made and repeated 3 times with $0.2 \mathrm{~mL}$ of the sample being injected each time. The camera settings for the instrument were set using the 'Autosettings' option on the software. The focus used was judged by eye, 
and was adjusted so that the majority of particles seen were in focus at any one time. The minimum expected particle size was set at $30 \mathrm{~nm}$ for all samples and the minimum track length set to automatic. The particle size distribution was measured three times. The software calculated the mean (the average particle size measured), mode (the most frequent particle size found) and standard deviation (the breadth of the log-normal distribution fitted to the data). In addition, each value is reported with its standard error. In this work the size is presented as mean values \pm standard error and standard deviation of the size distribution \pm standard error.

The particle size of mRNA polyplexes was measured using a Zetasizer Nano ZS (Malvern Instruments, Malvern, UK) and the data analysed by CONTIN method of analysis. Sizing was carried out at room temperature.

The zeta potential of the dispersion was measured using a Zetasizer Nano ZS (Malvern Instruments, Malvern, UK). The samples were prepared as previously described and incubated for $1 \mathrm{~h}$ at room temperature. A disposable folded capillary cell $(0.5 \mathrm{~mL})$ was used for zeta potential measurements. Zeta potential is presented as the average of three measurements \pm standard deviation.

\subsection{In Vitro Biological Characterisation of the Nucleic Acid Complexes}

\subsubsection{Heparin}

EAGC - nucleic acid complexes $\left(0.1 \mathrm{mg} \mathrm{mL}^{-1}\right.$ siRNA or DNA, $\left.10 \mu \mathrm{L}\right)$ were prepared as previously described and incubated for $1 \mathrm{~h}$ at room temperature. Heparin $\left(0.1 \mathrm{mg} \mathrm{mL}^{-1}\right.$ or 1 $\mathrm{mg} \mathrm{mL}^{-1}, 1 \mu \mathrm{L}$ ) was added to the complex dispersions and the dispersions incubated for 15 $\min$. Samples were subjected to gel electrophoresis (TAE buffer) for $1 \mathrm{~h}$ at $60 \mathrm{~V}$ in order to investigate the stability of the binding complex in the presence of heparin. The results were imaged as described above.

\subsubsection{Nuclease}

Resistance to nuclease digestion was determined using a deoxyribonuclease (DNase) and ribonuclease (RNase) protection assay. EAGC - nucleic acid (siRNA or DNA) complexes (0.1 
$\mathrm{mg} \mathrm{mL}^{-1}$ siRNA or DNA, $10 \mu \mathrm{L}$ ) were prepared as previously described and incubated for $1 \mathrm{~h}$ at room temperature. DNase or RNase $\left(1\right.$ unit $\left.\mu \mathrm{L}^{-1}, 1 \mu \mathrm{L}\right)$ was added to the complex or to naked DNA or siRNA. The samples were incubated at $37^{\circ} \mathrm{C}$ for $15 \mathrm{~min}$. Immediately following incubation, all samples were treated with ethylene diamine tetraacetic acid $(50 \mathrm{mM}, 10 \mu \mathrm{L})$ for 10 min to deactivate the DNase and RNase. Finally, heparin $\left(20 \mathrm{mg} \mathrm{mL}^{-1}, 1 \mu \mathrm{L}\right)$ was added and the mixture was incubated for $30 \mathrm{~min}$ at room temperature to dissociate the complex and thus examine the integrity of the nucleic acids. Samples were subjected to gel electrophoresis (with TAE buffer) for $1 \mathrm{~h}$ at $60 \mathrm{~V}$ to investigate the stability of the complex against enzymatic degradation. The results were imaged as described above.

\subsubsection{MTT Assay}

The MTT reagent [3-(4,5-Dimethyl-2-thiazolyl)-2,5-diphenyl-2H-tetrazolium bromide] was purchased from Alfa Aesar (Ward Hill, USA). Cells were seeded at 500 cells per well in 96well plates. They were allowed to grow for three days and then treated with EAGC17, EAGC21, EAGC29 or Lipofectamine 2000 (Invitrogen, Paisley, UK) at increasing concentrations ( $1 \times 10^{-9}$ to $10 \mathrm{mg} \mathrm{mL}^{-1}, 50 \mu \mathrm{L}$ per well) for $6 \mathrm{~h}$. In contrast, the cells were seeded at 10,000 cells per well and allowed to grow for 24 hours, then treated with either EAGC11 or EAGC22 at increasing concentrations $\left(2.4 \times 10^{-3}\right.$ to $5 \mathrm{mg} \mathrm{mL}^{-1}, 100 \mu \mathrm{L}$ per well) for $4 \mathrm{~h}$. Subsequently, cells were washed with Dulbecco's phosphate-buffered saline (DPBS, Invitrogen) and incubated for another 48h (EAGC17, EAGC21, EAGC29 and Lipofectamine 2000) or $24 \mathrm{~h}$ (EAGC11, EAGC22) with normal medium. The medium was discarded, cells washed with DPBS and the MTT solution $\left(50 \mu \mathrm{g}, 0.5 \mathrm{mg} \mathrm{mL}^{-1}, 100 \mu \mathrm{L}\right.$, 3-(4,5-Dimethyl-2thiazolyl)-2,5-diphenyl-2H-tetrazolium bromide) added. Cells were incubated with the MTT solution for $2 \mathrm{~h}$ at $37^{\circ} \mathrm{C}$, after which medium was removed, and dimethyl sulfoxide (DMSO, $100 \mu \mathrm{L}$ ) was added to each well to ensure complete solubilisation of the resulting formazan crystals. After incubation with DMSO for $10 \mathrm{~min}$ at $37^{\circ} \mathrm{C}$, the absorbance at $570 \mathrm{~nm}$ was measured using an ELx808 microplate reader (Bio-tek instruments, Potton, UK). For analysis, background values were subtracted. The cytotoxicity was determined as the ratio between the 
measured absorbance values of treated and untreated cells. Lysed cells (with Triton X-100, $21.4 \mathrm{mg} \mathrm{mL}-1,100 \mu \mathrm{L}$ per well) were used as a negative control (= $100 \%$ cell death).

The IC50 values (concentration of polymer at which $50 \%$ of cells are viable) were determined by analyses of the data using Prism4 software (GraphPad Software, Inc. La Jolla, USA). The sigmoidal dose response curve was analysed with Rmax fixed at 100 and $R$ min at 0 . Cytotoxicity results are presented as the average of three measurements \pm standard deviation.

\subsection{In Vitro Gene Transfection}

\subsubsection{General Method}

Briefly, 96-well plates were seeded with 10,000 cells (A431) per well and incubated overnight. The complexes were prepared to a final DNA concentration of $0.1 \mathrm{mg} \mathrm{mL}^{-1}$. Each polymer stock solution (EAGC17, EAGC21 and EAGC29) was prepared in sterile dextrose $(5 \% \mathrm{w} / \mathrm{v}$ filtered with a $0.22 \mu \mathrm{m}$ Millex filter) to which was added equal volumes of the DNA stock solution (in MiliQ water) to give polymer, DNA weight ratios of 1: 1 to $60: 1$. The complexes were allowed to incubate at room temperature, for 1 hour, after which the polymer - DNA complexes were added to the cells (50 $\mu \mathrm{L}, 1 \mu \mathrm{g}$ plasmid DNA per well) and incubated for $6 \mathrm{~h}$ in serum free Minimum Essential Medium (MEM, Life Technologies, Paisley, UK) or with MEM containing $10 \%$ serum (when the effect of protein was investigated). The complexes were then replaced with fresh MEM, the cells replenished with fresh MEM daily and the cells incubated for a further $48 \mathrm{~h}$. The transfection efficiency was determined by measuring the enzyme activity of $\beta$-galactosidase using the O-nitrophenylgalactoside (ONPG) assay in accordance with the manufacturer's instructions (Promega, Madison, USA). The cells were lysed by adding Triton $\mathrm{X}-100(2 \% \mathrm{w} / \mathrm{v}, 50 \mu \mathrm{L})$ and incubating the cells at $-80^{\circ} \mathrm{C}$ for at least $15 \mathrm{~min}$. After defrosting, deactivated Foetal Bovine Serum (FBS) $[0.5 \%$ v/v, $50 \mu \mathrm{L}$ in Dubelco's Phosphate Buffered Saline (DPBS)] was added to make the total volume to $100 \mu \mathrm{L}$. Finally, ONPG solution (2 mg $\mathrm{mL}^{-1}, 100 \mu \mathrm{L}$ ) was transferred to each well and the multiwall plates incubated for $1 \mathrm{~h}$. The absorption was measured at $420 \mathrm{~nm}$ in an ELx808 microplate reader. Values were expressed 
in $\mathrm{mU}$ per well and compared to the data observed with the naked plasmid DNA, polymer alone, untreated cells and the positive control Lipofectamine 2000.

Lipofectamine 2000 - DNA complexes were prepared at a ratio of $1 \mu \mathrm{g}$ DNA to $2.5 \mu \mathrm{L}$ Lipofectamine 2000 and prepared according to the manufacturer's instructions. The Lipofectamine 2000 complexes were used as a positive control. Cells were incubated for six hours with the Lipofectamine - DNA complexes ( $0.1 \mu \mathrm{g}$ DNA per well) in serum-free medium. The complexes were then replaced with fresh MEM. The cells were replenished with fresh MEM daily and the cells incubated for a further $48 \mathrm{~h}$.

\subsubsection{Transfection with Chloroquine}

Transfection experiments were carried out using chloroquine to investigate the stability of polyplexes in the endosome, following endosomal uptake of the polyplexes. All experiments were carried out as detailed above, except that the cells were incubated with cell medium containing $100 \mu \mathrm{M}$ chloroquine along with the polyplexes. The cells were transfected for 4 hours before the medium was changed.

\subsubsection{In vitro siRNA Transfection}

Briefly, 6-well plates were seeded with 500,000 cells (A431 cells) per well and incubated overnight. The complexes were prepared to a final ITCH siRNA/ scrambled siRNA (Eurofins mwg/operon, London, UK) concentration of $0.014 \mathrm{mg} \mathrm{mL}^{-1}$. Polymer stock solutions (EAGC29) were prepared in sterile dextrose $(5 \% \mathrm{w} / \mathrm{v})$ and filtered with a $0.22 \mu \mathrm{m}$ Millex filter. To the polymer solutions were added equal volumes of the ITCH siRNA/ scrambled siRNA stock solutions (in insiMAX universal buffer) to give formulations at a range of EAGC29, siRNA weight ratios. The complexes were allowed to incubate at room temperature for 1 hour, after which the EAGC29 - siRNA complexes were added to the cells $\left(0.014 \mathrm{mg} \mathrm{mL}^{-1}\right.$ siRNA, $750 \mu \mathrm{L}$, $10.68 \mu \mathrm{g}$ siRNA per well) and the cells incubated for $6 \mathrm{~h}$ in serum free medium (serum free MEM). The complexes were replaced with fresh complete MEM and the cells were then 
incubated for a further 48 hours. The transfection efficiency was determined by a Western blotting assay.

Lipofectamine 2000 - siRNA complexes were prepared according to the manufacturer's specifications and were used as a positive control. Cells were incubated for six hours with Lipofectamine 2000 - siRNA complexes $\left(0.003 \mathrm{mg} \mathrm{mL}^{-1}\right.$ siRNA, $500 \mu \mathrm{L}, 1.33 \mu \mathrm{g}$ per well), in serum-free medium and then replenished with fresh complete MEM.

Forty-eight hours after siRNA delivery, protein extracts were obtained from the A431 cells using lysis buffer containing protease inhibitors (Radio-Immunoprecipitation Assay (RIPA) buffer, Life Technologies, Paisley, UK). The protein content was determined with the Bicinchoninic Acid (BCA) Assay using Bovine Serum Albumin standards. $20 \mu \mathrm{g}$ of total protein was resuspended in NuPAGE® lithium dodecyl sulphate sample buffer and dithiothreitol sample buffer (both from Life Technologies, Paisley, UK), incubated for $15 \mathrm{~min}$ at $95^{\circ} \mathrm{C}$, and loaded onto a 4-12\% (gradient concentration) polyacrylamide gel (Life Technologies, Paisley, UK). After electrophoresis the proteins were blotted onto a nitrocellulose membrane. After blocking in $5 \%$ non-fat milk, overnight at 4 degrees, the membrane was incubated with an antiITCH (1: 500 dilution, BD Bioscience, San Jose, USA) and anti-actin antibody (1: 2500 dilution, Abcam, Cambridge, UK) for $2 \mathrm{~h}$ at room temperature, and with horseradish peroxidase (HRP) secondary antibody (1: 1000 dilution, Invitrogen, Paisley, UK) for $1 \mathrm{~h}$ at room temperature. Between the incubation periods the blots were washed two times with phosphate buffered saline (PBS, 1: 10 dilution) and three times with Tween $20(1 \% \mathrm{w} / \mathrm{v})$ in PBS. The membrane was incubated with SuperSignal West Pico Chemiluminescent Substrate (Thermo Scientific, Waltham, USA) for $5 \mathrm{~min}$ at room temperature and then submitted for detection with the ChemiDoc ${ }^{\mathrm{TM}}$ XRS + System (Bio Rad, Hemel, UK). For each membrane, the analysis of band intensity was performed using Image Lab software (BioRad, Hemel, UK). 


\subsubsection{In vitro mRNA transfection}

Briefly, 6-well plates were seeded with 500,000 cells (A431 cell line) per well and incubated overnight. The complexes were prepared to a final mRNA concentration of $5 \mu \mathrm{g} \mathrm{mL}^{-1}$. EAGC22 polymer stock solution and mRNA stock solution were prepared separately in sterile phosphate buffer [2 mM prepared with nuclease-free water (Qiagen, Manchester, UK). Equal volumes of polymer and mRNA stock solutions were combined at weight ratios of $30: 1,50: 1$ and 70: 1 . The complexes were allowed to incubate at room temperature for 1 hour, then were added to the cells ( $5 \mu \mathrm{g}$ mRNA in $0.5 \mathrm{ml}$ volume per well) and incubated for $4 \mathrm{~h}$ in Dulbecco's Modified Eagle's Medium (DMEM, 0.5mL per well). The complexes were then replaced with fresh DMEM containing $10 \%$ serum, and incubated for a further 24 h. The transfection efficiency was determined by measuring the $\beta$-galactosidase enzyme activity using the ONPG assay according to the manufacturer's instructions.

\subsection{In vivo administration of SiRNA}

Sprague Dawley rats (200-250 g) were housed four per cage in an air-conditioned unit maintained at $20-22^{\circ} \mathrm{C}$ and $50-60 \%$ relative humidity, and were allowed free access to standard rodent chow and water. Lighting was controlled on a twelve-hour cycle (lights on at $07.00 \mathrm{~h}$ and lights off at $19.00 \mathrm{~h}$ ). Animals were habituated for 7 days prior to experimentation and acclimatised to the procedure room for $1 \mathrm{~h}$ prior to testing at $08.00 \mathrm{~h}$. All protocols were conducted under a UK Home Office licence, in accordance with the Animals Scientific Procedures Act 1986 and approved by a local ethical committee.

Rats ( 2 for each study group) were intranasally administered with siRNA alone (15 $\mu \mathrm{g}, 40 \mu \mathrm{L}$ per nare, BLOCK-iT ${ }^{\mathrm{TM}}$ Alexa Fluor ${ }^{\circledR}$ Red Fluorescent Control, Life Technologies, Paisley, UK)

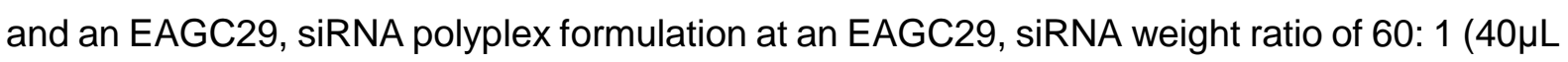
per nare, $15 \mu \mathrm{g}$ of siRNA, BLOCK-iT ${ }^{\text {TM }}$ Alexa Fluor ${ }^{\circledR}$ Red Fluorescent Control). Animals were briefly anesthetised with isoflurane and intranasally administered the formulation using an insulin syringe attached to PE10 tubing (15 mm). The tubing was inserted into one of the nares 
(Charlton et al., 2007). The brains were harvested after $5 \mathrm{~min}$, the olfactory bulbs separated, fixed in formalin and $0.5 \mathrm{~mm}$ thick coronal sections were prepared for microscopy.

\subsubsection{Coherent Anti-Stokes Raman Scattering (CARS) and Two Photon Fluorescence (TPF) Microscopy}

For CARS imaging, the dual wavelength picosecond excitation required was provided by an optical parametric oscillator (OPO) (Levante Emerald, APE, Berlin) pumped by a $532 \mathrm{~nm}$ beam generated by a frequency doubled Nd:Vanadium laser with a pulse width of 6 ps (Emerald Engine, APE, Berlin) directed into a modified commercial Olympus microscope, as described in our previous studies (Garrett et al., 2012). The laser fundamental at $1064 \mathrm{~nm}$ alone was used to excite (TPF), whereas CARS was generated with the fundamental $1064 \mathrm{~nm}$ beam as the Stokes beam and the OPO's signal beam as the pump. Both CARS and TPF signals were detected using a photomultiplier tube (R3896, Hamamatsu, Welwyn Garden City, UK) in the epi-direction, using a $750 \mathrm{~nm}$ long pass dichroic (750dcxr 229 Chroma, Yokohama, Japan) and two filters centred at $660 \mathrm{~nm}$ (Ealing Inc., Scotts Valley, USA) to separate the signal from the laser fundamental, using a 60× 1.0NA water immersion objective lens (LUMFI, 210 Olympus) to direct the laser light to the sample. All images were acquired with an approximately 11 seconds frame rate and a frame size of $512 \times 512$ pixels. The combined laser power was kept below $40 \mathrm{~mW}$ at the sample. This power was sufficiently low enough to prevent photo damage from occurring.

The CARS signal provided structural contrast from the samples, with the pump and Stokes beams tuned to excite the $\mathrm{CH}_{2}$ stretch at $2845 \mathrm{~cm}^{-1}$ (characteristic of lipid-rich structures such as myelin sheaths and lipid droplets etc.) For TPF imaging, the naturally occurring background fluorescence from the brain was separated from the particle fluorescence by adjusting the brightness and contrast of the images. With the PMT voltages used in these experiments, the 16-bit data sets (i.e. a possible pixel intensity range of 0 -65536) exhibited a maximum intensity value of approximately 270 for the control samples, and 4079 for the samples exposed to the fluorescent particles. 


\subsection{Statistical Analysis}

Data was analysed using Two Way ANOVA methods followed by Bonferroni post tests using

Prism 4 Software. Statistical significance was set at a $p$ value of less than 0.05 . 


\section{Results}

\subsection{Synthesis and Structural Characterisation of Ethylamino Glycol Chitosan}

A new polymer (EAGC) for nucleic acid delivery has been designed, synthesised and characterised by NMR and GPC-MALLS (Figure 1). The level of modification was calculated by comparing the substituted glycol chitosan C2-methines at $2.5 \mathrm{ppm}$ (diethylamine) and 2.7 ppm (monoethylamine) with the other sugar protons at $3.3-4.1 \mathrm{ppm}$.

Five different polymers were synthesised with different mole percentage levels of ethylamine substitution per GC monomer. EAGC11 has a degree of substitution of 11 mole\% (i.e. 11 moles of ethylamine groups per 100 moles of GC monomer), EAGC17 has a degree of substitution of 17 mole\%, EAGC21 of 21 mole\%, EAGC22 of 22 mole\% and EAGC29 of 29 mole\% (Table 1).

We observed the double substitution of the glycol chitosan C2 amino groups when the reaction was carried out at $40^{\circ} \mathrm{C}$. This is due to the reactivity of the secondary amine once formed as secondary amines have slightly higher pKa values than primary amines; they thus behave as stronger nucleophiles (Clayden et al., 2001; Solomons and Fryhle, 2011). The net result is the production of tertiary amines in the presence of the carbocation ethylamine electrophile. At room temperature we did not observe the double substitution of the glycol chitosan C2 amino group and substitution levels were reduced when the reaction was carried out at room temperature (Compare EAGC29 and EAGC11 - Table 1). As higher molecular weight GC was used to synthesise EAGC11, EAGC22 and EAGC29, the molecular weights of these polymers are higher than the molecular weights of EAGC17 and EAGC21. It should be noted that GC17 recorded a higher molecular weight than its substituted product, EAGC17. The molecular weight determination technique records the size distribution of a large number of individual molecules and we conclude that this molecular weight difference is evidence of the resolution limit of the technique. When the reaction was carried out at $40^{\circ} \mathrm{C}$, increasing the feed ratio of 2-tertbutoxycarbonylamino-ethyl bromide produced a more substituted polymer 
and hence manipulating the reaction stoichiometry and reaction temperature may be used to produce polymers with different levels of ethylamine substitution.

Unusually the level of secondary amine content remained at between 11.4 and $13.1 \mathrm{~mole} \%$ for all of the polymers prepared at a GC monomer, 2-tertbutoxycarbonylamino-ethyl bromide molar feed ratio of 1: 10 or less (Table 1), suggesting an upper limit of secondary amine modification and the increase in the overall substitution level observed was a direct result of an increase in the tertiary amine levels. This finding was consistent between the two molecular weight ranges studied $(17-18 \mathrm{kDa}$ and $25-29 \mathrm{kDa})$. It is noteworthy that when the $\mathrm{GC}$ monomer, 2-tertbutoxycarbonylamino-ethyl bromide molar feed ratio was 1: 40 (increasing the relative level of the amino alkyl reagent), the result was a polymer comprising only of tertiary amines (i.e. EAGC22, Table 1). A range of potential polymer vectors have been produced and these will be used to study the molecular variables governing the biological activity of these polymers. 
Table 1 - Characterization of EAGC polymers.

\begin{tabular}{|c|c|c|c|c|c|c|c|c|c|}
\hline Polymer & $\begin{array}{l}\text { GC, } \\
\text { tertbutoxycarbonylamino } \\
\text {-ethyl bromide feed ratio/ } \\
\text { Reaction temperature }\end{array}$ & \begin{tabular}{|l|}
\multicolumn{2}{|l|}{ Mole\% } \\
\multicolumn{2}{|l}{ substitution } \\
(moles of \\
ethylamine \\
per 100 \\
moles of \\
monomer)
\end{tabular} & $\begin{array}{l}\text { Mole\% } \\
\text { secondar } \\
\text { y amines }\end{array}$ & $\begin{array}{l}\text { Mole\% } \\
\text { tertiar } \\
y \\
\text { amine } \\
\text { s }\end{array}$ & $\begin{array}{l}\text { Mole\% } \\
\text { acetyl } \\
\text { group } \\
\text { s }\end{array}$ & $\begin{array}{l}M w \\
(k D a \\
)\end{array}$ & $\begin{array}{l}\text { Total } \\
\text { number of } \\
\text { amines per } \\
\text { polymer } \\
\text { chain }\end{array}$ & $\begin{array}{l}\text { Buffer } \\
\text { capacity (\%) }\end{array}$ & $\begin{array}{l}\text { IC50 in the } A 431 \\
\text { cell line }\left(\mathrm{mg} \mathrm{mL}^{-1}\right)\end{array}$ \\
\hline EAGC11 & 10: 1/ Room Temperature & 11 & 11.4 & 0 & 10.0 & 26.2 & 95 & 27 & $4.047 \pm 0.30^{*}$ \\
\hline EAGC17 & $2: 1 / 40^{\circ} \mathrm{C}$ & 17 & 13.1 & 3.8 & 9.3 & 16.9 & 63 & 38 & $1.826 \pm 0.09$ \\
\hline EAGC21 & $5: 1 / 40^{\circ} \mathrm{C}$ & 21 & 12.3 & 9.1 & 9.7 & 17.6 & 67 & 50 & $0.863 \pm 0.16$ \\
\hline EAGC29 & 10: $1 / 40^{\circ} \mathrm{C}$ & 29 & 12.9 & 15.6 & 9.0 & 29.9 & 118 & 86 & $0.522 \pm 0.17$ \\
\hline EAGC22 & $40: 1 / 40^{\circ} \mathrm{C}$ & 22 & 0 & 21.7 & 9.9 & 25.5 & 106 & 26 & $0.373 \pm 0.054^{*}$ \\
\hline
\end{tabular}

${ }^{*}$ Polymer incubated with cells for only 4 hours and cytotoxicity measured 24 hours after removal of the polymer, while other polymers incubated for 6 hours and cytotoxicity measured 48 hours after removal of the polymer. 
The potentiometric titration curves of the GC and EAGC polymers (Figure 2) were based on the following chemical reaction:

$$
\mathrm{HCl}+\mathrm{GC}-\mathrm{NR}_{2} \mathrm{H}^{+}+\mathrm{NaOH} \leftrightarrow \mathrm{NaCl}+\mathrm{GC}-\mathrm{NR}_{2}+\mathrm{H}_{2} \mathrm{O}
$$

where $\mathrm{R}$ is either hydrogen or the ethylamine group. Interestingly Figure 2 shows two inflection points: the first point corresponds to the neutralization of excess hydrochloric acid and the second to the neutralization of the available amine hydrochloride groups on EAGC. It was not possible to separate out the neutralization of primary, secondary and tertiary amine hydrochloride groups, and hence calculate the correspondent pKa values, due to the heterogeneity of the polymer. Instead the buffer capacity was determined as this is relevant to the polymer's ability to buffer and then escape the acidic endosome compartment.

The volume of $\mathrm{NaOH}(0.05 \mathrm{M})$ required to bring the $\mathrm{pH}$ from 5.1 to 7.5 in the case of EAGC11, EAGC17, EAGC21, EAGC22 and EAGC29 was higher than the volume of base required for GC17 (Table 1). This indicated the new polymers had a higher buffer capacity, when compared with GC17. The buffer capacity of the different types of EAGCs is defined as the percentage of amino groups that become protonated in the $\mathrm{pH}$ range 5.1 to 7.4 . Increasing the degree of ethylamine substitution increased the buffer capacity of the EAGCs (Table 1). These new alkylamines, unlike the primary amines of $\mathrm{GC}(\mathrm{pKa}=6.41 \pm 0.05)$ (Chooi et al., 2014) would have pKa values (Piest and Engbersen, 2010; Wang et al., 2002), in the range of $9-10$ and consequently these new alkylamines increased the buffering capacity of the polymers. EAGC22, with only tertiary amines, had a lower buffer capacity when compared with a comparable polymer with a mixture of secondary and tertiary amines (e.g. EAGC21, Table 1). This is not surprising as tertiary amines usually have a lower pKa than secondary amines (Sykes, 1986). 


\subsection{Physical Characterization of EAGC - Nucleic acid Particles}

\subsubsection{Agarose gel retardation essay}

Agarose gel electrophoresis was performed to investigate the binding between the EAGC polymers and plasmid DNA, mRNA and siRNA (Figure 3). The complexes were allowed to interact for $30 \mathrm{~min}$ or $1 \mathrm{~h}$ before being subjected to electrophoresis. The naked nucleic acids were used as controls. GC17 was unable to condense DNA (Figure $3 a$ and $3 b$ ). This was due to the non-protonation of the primary amines in the glycol chitosan backbone at physiological $\mathrm{pH}$, since the pKa of GC is $6.41 \pm 0.05$ (Chooi et al., 2014). Non-protonated amine groups will be unable to electrostatically complex with the negatively charged plasmid DNA. 
The introduction of new alkylamine moieties, which are presumably protonated at physiological $\mathrm{pH}$, enabled the EAGC polymers to electrostatically bind to the anionic nucleic acids and form nanoparticles. The less substituted polymers (EAGC17 and EAGC21) were less efficient at condensing DNA than the more heavily substituted polymer (EAGC29). EAGC17 and EAGC21 were unable to condense plasmid DNA within the 30min incubation period at polymer, DNA weight ratios of less than 20: 1 or 10: 1 respectively (Figures 3c and 3e) and only able to condense DNA after one hour of incubation at a ratio of 10: 1 and above for EAGC17 (Figure 3d) and at all weight ratios with EAGC21 (Figure 3f). Increasing the degree of substitution (e.g. with EAGC29) enabled DNA condensation at polymer, DNA weight ratios of 5: 1 and above (Figure $3 g$ and $3 h$ ). Hence increasing the buffering capacity of GC with the addition of basic amine groups transformed GC into a DNA polyplex forming polymer. Furthermore increasing the density of amine groups per polymer increased the DNA binding capacity of the polymers.

EAGC29 was more efficient at complexing DNA than siRNA. While DNA complexation with EAGC29 occurred at polymer, DNA weight ratios of 5 and above (Figures $3 \mathrm{~g}$ and $3 \mathrm{~h}$ ), complexation of EAGC29 with siRNA occurred at polymer, DNA weight ratios of 10 and above (Figures $3 \mathrm{i}$ and $3 \mathrm{j}$ ). It has been reported that siRNA - chitosan polyplexes are less stable, when compared with DNA polyplexes with chitosan (Liu et al., 2007). The explanation given for this observation centred on the relative ease with which a longer polynucleotide chain would interact with multiple chitosan polymer chains when compared to a shorter polynucleotide chain (Liu et al., 2007). It is our opinion that a similar phenomenon is operating with EAGC29 and DNA is thus easier to complex than siRNA. mRNA was effectively complexed by EAGC11 at all the weight ratios tested (Figure $3 \mathrm{k}$ ).

\subsubsection{Transmission Electron Microscopy}

Morphological characterization of the nanoparticles formed between EAGC17, EAGC21 and EAGC29 and both DNA and siRNA was performed using transmission electron microscopy 
(TEM, Figure 4). Prior to condensation, both naked DNA and naked siRNA were visible as electron dense fibres (due to the staining of the hydrophilic DNA - Figures $4 \mathrm{a}$ and $4 \mathrm{e}$ ) whereas on condensation with the polymers, electron dense $100-400 \mathrm{~nm}$ spherical nanoparticles were formed (Figures $4 b-d$ and Figure 4f). Toroidal structures were visualised with EAGC29 siRNA polyplexes (Figure 4f).

The TEM data provide further evidence of polyplex formation.

\subsubsection{Size and Zeta Potential}

Polymer, nucleic acid (siRNA and DNA) complex particle size was determined by nanoparticle tracking analysis (Figures 5a and b, Table 2) and particles were $150-400 \mathrm{~nm}$ in size (Figured $5 \mathrm{a}$ and $\mathrm{b}$ and Table 2), with the size data in broad agreement with the TEM data (Figure 4). At a polymer, DNA weight ratio of 5: 1 or higher, positively charged complexes were produced (Figure $5 \mathrm{c}$ and $5 \mathrm{~d}$ ) with all three polymers and the positive zeta potential is evidence of DNA complexation within the nanoparticle as shown by the electrophoresis data (Figure $3 \mathrm{a}-\mathrm{h}$ ) and the coating of the polyplex with the polycation polymer. EAGC29, DNA complexes had a higher zeta potential at a polymer, DNA weight ratio of 60: 1, when compared to lower polymer, DNA weight ratios (Figure $5 c$ ) and this may be due to the presence of a higher number of protonated amine groups in the polyplex at the polymer, DNA weight ratio of 60: 1. At a polymer, DNA weight ratio of 1: 1, the formulations presented with a negative zeta potential (Figure 5c) and DNA was not fully complexed with the polymer (Figure $3 d, f$ and $h$ ). At the lower polymer, DNA weight ratios (1:1, 5: 1, 10: 1 and 30:1), EAGC17 produced slightly larger complexes than at the higher polymer, DNA weight ratios and this data correlates with certain elements of the agarose gel electrophoresis data, showing that DNA was only fully complexed by EAGC17 at a polymer, weight ratio of 10: 1 and above (Figure 3d).

The higher the charge density on the polymers (charge density follows the trend: EAGC17 < EAGC21 < EAGC29), the fewer polymer chains that would be sufficient to form compact electrostatic complexes with the negatively charged DNA, hence more compact complexes 
are formed with EAGC17 and DNA at higher polymer, DNA weight ratios (40: 1, 50: 1 and 60: 1). The size of the EAGC21, DNA complexes did not change with polymer, DNA weight ratios and $200 \mathrm{~nm}$ complexes were formed at all polymer, DNA weight ratios (Figure 5a and 3f).

Interestingly EAGC29, DNA complexes were significantly larger than the other polymer complexes at the higher polymer, DNA weight ratios (40:1,50:1 and 60: 1). It is possible that the higher molecular weight of EAGC29 led to this observation as polymer molecular weight correlates positively with nanoparticle size (Wang et al., 2001). Once siRNA was fully complexed by EAGC29 (i.e. at a polymer, siRNA weight ratio equal to 10:1 or higher - Figure 3i), $200 \mathrm{~nm}$ complexes were formed with no change in complex particle size as the level of polymer in the formulation was increased. At the lower EAGC29, siRNA weight ratio of 1: 1, siRNA was not complexed with EAGC29 (Figure 3j) and the formulation presented with a negative zeta potential (Figure 5d).

EAGC11, mRNA polyplexes were $150-200 \mathrm{~nm}$ in size, as determined using an alternative sizing method (Malvern Zetasizer) and these were similar in size to the siRNA complexes. Polyplexes were positively charged, which suggests effective complexation, and correlates well with the gel electrophoresis data (Figure 3k). 
Table 2: Mean Size and Size Distribution Standard Deviation of EAGC, Nucleic Acid Complexes*

\begin{tabular}{|c|c|c|c|c|c|c|c|c|}
\hline $\begin{array}{c}\text { Polymer, } \\
\text { Nucleic } \\
\begin{array}{c}\text { acid } \\
\text { Weight ratio }\end{array}\end{array}$ & $\begin{array}{c}\text { Eean Size } \pm \\
\text { sem }(\mathrm{nm})\end{array}$ & $\begin{array}{c}\text { Standard } \\
\text { Deviation } \\
\pm \text { sem }(\mathrm{nm})\end{array}$ & $\begin{array}{c}\text { Mean Size } \\
\pm \mathrm{sem} \\
(\mathrm{nm})\end{array}$ & $\begin{array}{c}\text { Standard } \\
\text { Deviation } \pm \\
\text { sem }(\mathrm{nm})\end{array}$ & $\begin{array}{c}\text { Mean Size } \\
\pm \text { sem } \\
(\mathrm{nm})\end{array}$ & $\begin{array}{c}\text { Standard } \\
\text { Deviation } \pm \\
\text { sem }(\mathrm{nm})\end{array}$ & $\begin{array}{c}\text { Mean Size } \\
\pm \text { sem } \\
(\mathrm{nm})\end{array}$ & $\begin{array}{c}\text { Standard } \\
\text { Deviation } \\
\pm \mathrm{sem}(\mathrm{nm})\end{array}$ \\
\hline 1 & $356 \pm 22$ & $140 \pm 18$ & $157 \pm 3$ & $82 \pm 5$ & $169 \pm 6$ & $47 \pm 1$ & $484 \pm 54$ & $217 \pm 35$ \\
\hline 5 & $401 \pm 12$ & $178 \pm 19$ & $222 \pm 3$ & $96 \pm 3$ & $221 \pm 3$ & $183 \pm 5$ & $225 \pm 11$ & $101 \pm 10$ \\
\hline 10 & $338 \pm 12$ & $130 \pm 11$ & $228 \pm 3$ & $102 \pm 4$ & $143 \pm 6$ & $66 \pm 2$ & $167 \pm 3$ & $85 \pm 1$ \\
\hline 20 & $187 \pm 4$ & $87 \pm 3$ & $184 \pm 3$ & $93 \pm 7$ & $206 \pm 4$ & $101 \pm 5$ & $218 \pm 19$ & $99 \pm 6$ \\
\hline 30 & $299 \pm 4$ & $99 \pm 3$ & $174 \pm 1$ & $86 \pm 2$ & $225 \pm 4$ & $130 \pm 5$ & $205 \pm 13$ & $106 \pm 7$ \\
\hline 40 & $183 \pm 2$ & $79 \pm 1$ & $212 \pm 3$ & $91 \pm 1$ & $243 \pm 5$ & $118 \pm 6$ & $254 \pm 9$ & $120 \pm 7$ \\
\hline 50 & $281 \pm 3$ & $100 \pm 4$ & $296 \pm 6$ & $106 \pm 7$ & $441 \pm 18$ & $181 \pm 23$ & $278 \pm 10$ & $139 \pm 2$ \\
\hline 60 & $167 \pm 3$ & $79 \pm 1$ & $242 \pm 10$ & $129 \pm 13$ & $347 \pm 6$ & $153 \pm 4$ & $255 \pm 5$ & $135 \pm 1$ \\
\hline
\end{tabular}

*mean \pm SEM of size and size distribution standard deviation of three separate experiments, nucleic acid concentration $=0.1 \mathrm{mg} \mathrm{mL}-1$, formulations were prepared in dextrose $(5 \% \mathrm{w} / \mathrm{v})$ and incubated for one hour prior to analyses. 


\subsection{In vitro Biological Characterisation of EAGC - Nucleic acid Particles}

\subsubsection{Incubation with Heparin and Deoxyribonuclease}

In the extracellular compartments, the presence of negatively charged molecules such as serum albumin and other extracellular proteins that may interact with the positively charged nanoparticles may introduce instability in the gene delivery systems (Wiethoff and Middaugh, 2002). These anionic molecules may lead to aggregation of the nanoparticles, by charge neutralisation of the particle surface charge and lead to displacement of the nucleic acids from the delivery system due to competition (Wiethoff and Middaugh, 2002).

The stability of the complexes in the presence of biological polyanions was thus examined by incubation with heparin (Figure 6). Heparin is known to displace nucleic acids from polyplexes (lemsam-Arng et al., 2014). At the lower heparin concentration $\left(0.1 \mathrm{mg} \mathrm{mL}^{-1}\right)$ the stability of the complexes followed the trend: EAGC29 > EAGC21 > EAGC17, whereas at the higher heparin concentration $\left(1 \mathrm{mg} \mathrm{mL}^{-1}\right)$ the stability of the complexes followed the trend: EAGC29 > EAGC21 $=$ EAGC17. The higher charge density of the EAGC29 polymer (a higher number of amine groups per molecule - Table 1) led to the creation of more stable complexes (Figure 6).

A polymer, siRNA weight ratio of $60: 1$ was required to resist the displacement of siRNA by heparin, when heparin was added at a concentration of $0.1 \mathrm{mg} \mathrm{mL}^{-1}$ (Figure $6 \mathrm{~d}$ ), indicating that the siRNA formulations were marginally less stable than the DNA formulations (Figure 6c). With DNA, stable polyplexes (stable to heparin displacement, heparin concentration = $0.1 \mathrm{mg} \mathrm{mL}^{-1}$ ) were produced at a polymer, DNA weight ratio of 10: 1 (Figure 6c). With $1 \mathrm{mg}$ $\mathrm{mL}^{-1}$ heparin all EAGC29, siRNA complexes were destabilised (Figure 6d). It is clear that the DNA polyplexes are more stable than the siRNA polyplexes.

One of the challenges upon administration of nucleic acids in vivo is the presence of endogenous nucleases (Alameh et al., 2012). Deoxyribonuclease (DNAse) is an endonuclease that hydrolyses the double-stranded DNA and is one of the major barriers for 
gene delivery. Unprotected DNA is easily degraded by DNAse in a matter of minutes (Figure $7 a-c)$.

Complexes were incubated with DNAse or DNAse plus heparin; the incubation with heparin was carried out in order to observe the quality of DNA present in the complexes after incubation with DNAse. First of all EAGC, DNA formulations at a EAGC, DNA weight ratio of 60 were not sufficiently destabilised by heparin to observe the effects of DNAse on the erstwhile complexed DNA and so this particular group of formulations could not be adequately evaluated (Figure 7a-c). Complexes prepared from EAGC17 and EAGC21 at a polymer, DNA weight ratio of 30: 1 or less all resulted in the destruction of DNA on incubation with DNAse (observed as a multiple bands of nucleic acid fluorescence - Figures $7 \mathrm{a}$ and $7 \mathrm{~b}$ ). Whereas similar complexes prepared from EAGC29 resulted in DNA remaining intact and undegraded by DNAse (Figure 7c).

RNase is an endonuclease that hydrolyses siRNA, completely degrading it in minutes (Figure 7d). In a similar manner to DNase, RNase is present in vivo in the extracellular and intracellular spaces, and is one of the major barriers for siRNA delivery (Abdelhady et al., 2003). EAGC29 protected siRNA from RNAse degradation at all EAGC29, siRNA weight ratios.

It is clear that EAGC29, nucleic acid formulations were stable to destabilisation by anions and by nucleases.

\subsubsection{Cell Cytotoxicity Assay}

The IC50 for Lipofectamine 2000 was $0.071 \mathrm{mg} \mathrm{mL}^{-1}$ (Figure 8). All the EAGC polymers were significantly $(p<0.05)$ less cytotoxic than Lipofectamine 2000 with IC50 values ranging from $0.373 \pm 0.054-4.047 \pm 0.30 \mathrm{mg} \mathrm{mL}^{-1}$ (Table 1 and Figure 8 ). EAGC11 was the least toxic polymer although it must be stated that this polymer was only incubated with the cells for $4 \mathrm{~h}$ and not for $6 \mathrm{~h}$, due to this being the length of time EAGC11 was in contact with the cells during the transfection study. EAGC17 was significantly less cytotoxic than EAGC21 and EAGC29 $(p<0.001)$. All the EAGC polymers were less toxic than branched PEI (IC50 in the 
A431 cell line $\left.=0.0019 \mathrm{mg} \mathrm{mL}^{-1}\right)($ Brownlie et al., 2004), the diaminobutane dendrimers (IC50 in the A431 cell line $\left.=0.039 \mathrm{mg} \mathrm{mL}^{-1}\right)$ (Zinselmeyer et al., 2002) and linear PEI $\left(0.074 \mathrm{mg} \mathrm{mL}^{-}\right.$ ${ }^{1}$ in the A431 cell line) (Kafil and Omidi, 2011).

To examine the influence of molecular structure on cell cytotoxicity, all cytotoxicity data was treated in a similar manner, despite the differences in cell incubation times. Interestingly, Table 1 shows there is not a simple correlation between the number of amines in the polymer and toxicity. EAGC11 has more amines than both EAGC17 and EAGC21, due to its increased size, but has a higher IC50 value. However there was a negative correlation between the degree of tertiary amine substitution (DS tert) and the IC50 (Figure 8b) as shown in Equation 1

$$
\text { IC50 = 6.18 DS } \text { tert }^{-0.90}\left(r^{2}=0.9991\right)
$$

The tertiary amine density is a significant driver of toxicity (Equation 1) and even when the level of secondary amines are fixed, there is still a negative correlation between the degree of tertiary amine substitution ( $\left.\mathrm{DS}_{\text {tert1 }}\right)$ in polymers containing both secondary and tertiary amines (EAGC17, EAGC21 and EAGC29) and the IC50 (Equation 2).

IC50 $=5.98$ DS $_{\text {tert1 }}^{-0.88}\left(r^{2}=0.9995\right)$

It is our opinion that as far as possible tertiary amines should be avoided in the construction of polyamine vectors and the toxicity of tertiary amines is even reflected in the comparable toxicity of linear PEI [devoid of tertiary amines, IC50 $=0.074 \mathrm{mg} \mathrm{mL}^{-1}$ in the A431 cell line (Kafil and Omidi, 2011)] and branched PEI [containing tertiary amines, IC50 = $0.0019-0.0036$ $\mathrm{mg} \mathrm{mL}^{-1}$ in the A431 cell line (Brownlie et al., 2004; Cheng et al., 2006)]. When compared to existing and commercial transfection vectors, it is concluded that more biocompatible polymers have been created in our work and that these polymers are able to complex with nucleic acids and protect these nucleic acids from degradation by endonucleases and displacement by anionic biopolymers. The next test is to examine if these polymers are 
capable of transferring nucleic acids into cells and achieving either protein expression of an exogenous gene or protein down regulation of an endogenous gene.

\subsubsection{Plasmid Transfection efficiency}

The transfection efficiencies of the new EAGC polymers were evaluated using both DNA and siRNA. In the first instance all polymers were able to deliver plasmid DNA to the A431 cells and enable the exogenous protein ( $\beta$-galactosidase) to be expressed (Figure 9). Lipofectamine 2000 was used as a positive control in accordance with the manufacturer's instructions and applied at a plasmid concentration of $0.1 \mu \mathrm{g}$ per well, whereas the EAGC polyplexes were applied at a plasmid concentration of $1 \mu \mathrm{g}$ per well. The use of higher levels of plasmid with Lipofectamine was not possible due to the cytotoxicity of the lipid.

All the polymers showed poor transfection at a polymer, DNA weight ratio of $1: 1$, evidence that DNA complexation (Figure $3 d, f$ and $h$ ) is required for transfection. EAGC21 and EAGC29 polyplexes produced significantly more protein expression when compared to EAGC17 at the 5, 10, 20 and 30 polymer, DNA weight ratio, indicating that a higher charge density on the polymers (Table 1) and thus a greater ability to complex DNA (Figure 3) promoted transfection (Figure 9d). At the polymer, DNA weight ratios above 20: 1, all the polyplexes produced protein expression that was in excess of that seen with DNA alone (Figure 9). At the polymer, DNA weight ratio of 60 , EAGC29 was less efficient than when used at lower polymer, DNA weight ratios (Figure 9c). This polymer was the most cytotoxic of the three polymers used (Table 1) and at an EAGC29, polymer weight ratio of 60: 1 and when adding $1 \mu \mathrm{g}$ DNA per well, the concentration of EAGC29 used would be $0.6 \mathrm{mg} \mathrm{mL}^{-1}$, which is very close to the IC50 of EAGC29 $\left(0.523 \pm 0.17 \mathrm{mg} \mathrm{mL}^{-1}\right.$, Table 1$)$. It is thus possible that this cytotoxicity reduced the observed protein expression. Peak transfection activity was observed with EAGC17, EAGC21 and EAGC29 at polymer, DNA weight ratios of 60: 1, 30: 1 and 30: 1 respectively. 
It is clear that an increase in the density of amines per polymer molecule promotes gene complexation, and thus gene transfer into cells but that the density of amines requires to be controlled so as not to produce a polymer formulation that is inherently cytotoxic.

\subsubsection{Effect of Chloroquine}

We sought to determine if the transfection efficiency of a representative EAGC polymer (EAGC21) would be improved in the presence of chloroquine. Chloroquine increases the $\mathrm{pH}$ of the endosome (Murphy et al., 1984) and in turn increases the transfection efficiency of polymers, not only by buffering the endosome but also by possibly dissociating the polymers from the nucleic acids (Erbacher et al., 1996). The application of chloroquine did not improve the transfection efficiency (Figure 9e) of the EAGC polymer or of Lipofectamine 2000 but actually decreased protein expression at the lower polymer, DNA weight ratios. It is conceivable that at low polymer, DNA weight ratios, chloroquine could have resulted in the premature displacement of the nucleic acid from the polyplexes, thus resulting in reduced protein expression. However the results are by no means conclusive and further in depth examination of the effect of chloroquine is warranted.

\subsubsection{Presence of proteins}

We then set out to examine the effect of proteins on the transfection efficiency of the polymers, using EAGC21 as a representative polymer. Serum proteins are known to destabilise polyplexes (lemsam-Arng et al., 2014).

There was minimal impact on transfection from the presence of proteins in the media (Figure 9f), with only the EAGC21 polyplexes showing a decrease in transfection efficiency at a polymer, DNA weight ratio of 30 in the presence of protein and a slight increase in transfection efficacy observed at a polymer, DNA weight ratio of 50 in the presence of proteins. As the changes in transfection efficacy were, in essence, a 25\% drop in protein expression (at a polymer, DNA weight ratio of 30 ) and a $20 \%$ increase in protein expression (at a polymer, DNA weight ratio of 50: 1), we conclude that proteins have a minimal effect on the in vitro 
transfection efficacy of the EAGC21 polymer and that the level of protein used in our in vitro experiments did not lead to any material changes in target protein expression. Others have reported that serum does not lead to a change in protein expression with chitosan based delivery systems also (Erbacher et al., 1998; Mao et al., 2001).

\subsection{6 mRNA Delivery}

Figure 10 demonstrates that EAGC22 was able to transfer mRNA into cells, which then was translated into functional protein. Polyplexes with EAGC22 at polymer : mRNA weight ratio 70:1 showed highest transfection efficiency. The transfection efficiency of EAGC22 was comparable to that shown by the commercial transfection - reagent JetPEI.

\subsection{7 siRNA Gene Silencing Efficiency}

We then sought to examine the ability of the most substituted polymer (EAGC29) to deliver siRNA to A431 cells. Anti-ITCH siRNA (de la Fuente et al., 2015) was used in these studies. ITCH is an ubiquitin ligase that is involved in controlling cell growth, differentiation and apoptotic process. Its targets are transcription factors and growth factor receptors that act as gene expression regulators (Melino et al., 2008). The data in Figure 11 show increasing levels of ITCH gene knock down with increasing polymer, siRNA weight ratios. The knockdown observed is specific for the ITCH gene as the control samples (Scrambled siRNA) do not show any gene silencing. 


\subsection{In vivo siRNA Delivery}

The aim of our work is to produce biocompatible nucleic acid transfer systems that may be used via the nose to brain route to achieve brain gene silencing. Hence a preliminary nose to brain delivery study was carried out in a healthy rat model in order to see if intact siRNA could be delivered to neuronal cells.

Figure 12 shows the CARS images of ex-vivo brain samples from representative animals in groups of treated and untreated mice. Untreated animals show no sign of siRNA fluorescence (Figure 12a). 5 minutes after administration of the EAGC29, siRNA (polymer, siRNA ratio = 60: 1) formulation, siRNA fluorescence was seen in the olfactory bulb (Figure 12c) and the signal was 12 times higher when compared to the signal seen in the olfactory bulbs from animals that had been dosed with siRNA alone (Figure 12b). These images demonstrate that nasal delivery to the olfactory bulb was achieved with fluorescent siRNA EAGC29 formulations. These preliminary results introduce EAGC29 as a good candidate for subsequent in vivo studies of siRNA delivery to the brain. To establish these delivery systems as suitable nose to brain vectors, further work will need to address the biodistribution of the nanoparticles to the different tissues of the brain as well as the pharmacological activity of the systems.

\section{Discussion}

The absence of biocompatible delivery systems continues to be the single reason why gene therapy has yielded only a handful of registered products (Miller, 2012; Peng, 2005). Despite considerable investment (Ledley et al., 2014) gene therapy either in the form of RNA or DNA actives has not fulfilled its potential. Our aim is to prepare biocompatible nucleic acid delivery systems that may be used to achieve nose to brain gene silencing and we hypothesise that by limiting the density of the amine moieties on a polymeric delivery system, we would produce an efficient delivery system with minimal cell cytotoxicity. There is evidence from the diaminobutane dendrimer series that a larger number of amines per molecule (a higher 
molecular weight) is correlated with increasing cytotoxicity (Zinselmeyer et al., 2002) and that primary amine polymers are more toxic than polymers containing carboxylate surface groups (Malik et al., 2000). Furthermore functionalising PEI primary amines with poly(ethylene glycol), quaternary ammonium or palmitoyl moieties also led to a reduction in PEI cell cytotoxicity (Brownlie et al., 2004). However these structural modifications also led to a reduction in transfection efficiency (Brownlie et al., 2004). Clearly it is important to control the number of amine groups, as amine groups are essential for synthetic vector gene transfer, but we also need to ensure that we do not produce polymer vectors with unacceptable cell cytotoxicity. Our understanding of the proportion of amine groups required for efficient transfection is not yet concrete although we recently reported an in vitro and in vivo gene delivery polymer; a poly(ethylene glycol) based polyamine (tetra-O,O,O,Opoly(ethyleneglycol-O-2-ethyleneimine - 4APEA), which has an IC50 of $4.76 \pm 0.27 \mathrm{mg} \mathrm{mL}-1$ in the A431 cell line (lemsam-Arng et al., 2014) and is relatively biocompatible and yet efficient as a gene transfer agent. In this work we set out to see if we could achieve the right density of amines on the polymer to effect gene transfer without compromising cell biocompatibility. GC contains amine groups with a low pKa of $6.41 \pm 0.05$ (Chooi et al., 2014) and hence these GC amines will not be protonated at physiological pH (have a low buffering capacity - Table 1, Figure 2) and are unable to complex with DNA (Figure $3 a$ and b). Adding the new alkylamine moieties to GC to produce EAGC, resulted in polymers with a higher buffering capacity (indicative of a higher pKa - Table 1, Figure 2) and endowed these polymers with the ability to condense nucleic acids (Table 2, Figure 3, Figure 4b, c, d and f, Figure 5) and form positively charged (Figure 5c and d), $150-400 \mathrm{~nm}$ (Figure 5a and b), spherical and toroidal (Figure 4b,c, $d$ and f) polyplexes. The ability to complex DNA and protect DNA from degradation increased as the density of ethylamino groups increased (Figure $3 c-3 h$, Figures 6 and 7) and this is in agreement with the literature (Lu et al., 2009; Rungsardthong et al., 2003). Only highly deacetylated chitosans for example are able to complex with DNA (Hoggard-Koping et al., 2001). However increasing the level of ethylamino groups per molecule also led to an increase in cell cytotoxicity (Table 1, Figure 8, Figure 9), although 
crucially all polymers were $1-3$ orders of magnitude less cytotoxic than Lipofectamine 2000 (Figure 8) and both linear (Kafil and Omidi, 2011) and branched (Brownlie et al., 2004; Cheng et al., 2006) PEI. This is important, as linear PEI has been locally administered to patients in clinical trials (Gofrit et al., 2014).

Surprisingly we found that the cytotoxicity (IC50) of these new polymers was inversely correlated with the density of the tertiary amine groups (Equation 1). These findings of a mathematical relationship between cytotoxicity and polymer structure open up the possibility that polymers with a desired biocompatibility profile may be dialed up in the future.

Our work shows that high pKa primary and secondary amines appear to be important for nucleic acid polyplex formation and cell transfer whereas tertiary amines are detrimental to the cell transfer process due to their correlation with cell cytotoxicity.

These new EAGC polymers are able to transfect cells with DNA, siRNA and mRNA (Figures 9 - 11) with an efficiency often comparable to commercial reagents such as Lipofectamine 2000 or JetPEI. EAGC21 and EAGC29 proved particularly efficient for the DNA delivery (Figure 9) and EAGC22 provided a good level of mRNA transfer into cells (Figure 10).

It is envisaged that these polyplexes would enter the cell by endocytosis as has been reported for other polyplexes (Akinc and Langer, 2002) and as such the increased buffering capacity of the more substituted polymer (EAGC29) should enable this polymer to escape the acidic endosome, in accordance with the proton sponge hypothesis, although it must be stated that the hypothesis itself has been called into question by the observation that poly(ethylenimine), for example, does not raise lysosomal pH (Benjaminsen et al., 2013).

When comparing polymers of similar molecular weight: EAGC17 (Mw $=16.9 \mathrm{kDa})$ and EAGC21 $(17.6 \mathrm{kDa})$, it is clear that an increase in the density of ethylamine groups produces a polymer that has a higher buffer capacity (Table 1, Figure 2), is more efficient at complexing DNA (Figure $3 e-3 i)$ and forming stable complexes, which resists degradation by polyanions 
(Figure 6a and b) and nucleases (Figure 7a and b). These attributes also lead to improved gene transfer (Figure 9d). It is not clear that increasing both the molecular weight and the level of ethylamine groups, as in EAGC29, actually leads to an improved DNA vector (Figure 9d), despite the fact that EAGC29 is most efficient at protecting DNA from nuclease degradation (Figure 7).

We can conclude that substituting GC with 20 mole\% ethylamine groups, limiting the level of tertiary amines and with the polymer having a final molecular weight of $17 \mathrm{kDa}$ are ideal parameters for gene transfer. Previously we have reported that a degree of polymerization (DP) of 86 in other glycol chitosan derivatives was the ideal molecular weight for gene delivery in vivo, i.e. a molecular weight of approximately $18-20$ kDa (Uchegbu et al., 2004) and hence the current data is in agreement with previous findings. There has been much debate in the literature on the ideal molecular weight to use for nucleic acid delivery with chitosan and its derivatives, with some reports advocating a high molecular weight of $100-400 \mathrm{kDa}$ (Delgado et al., 2013; Huang et al., 2005; Ishii et al., 2001; MacLaughlin et al., 1998; Mao et al., 2001) and others advocating the use of chitosans with a molecular weight of less than $100 \mathrm{kDa}$ (Erbacher et al., 1998; Hoggard-Koping et al., 2001; Holzerny et al., 2012; Jorgensen et al., 2012; Lee et al., 2001; Strand et al., 2010; Techaarpornkul et al., 2010). Our data consistently show that chitosan derivatives with molecular weights of less than $30 \mathrm{kDa}$ have the right balance of cytotoxicity and nucleic acid complexation, protection and transduction activity (Uchegbu et al., 2004) (Figure 9d). The fact that the lower molecular weight glycol chitosan derivatives are efficient gene transfer agents is pertinent, as high molecular weight chitosans are correlated with cytotoxicity, e.g. chitosans of high molecular weight (>100 kDa) and with a high degree of deacetylation (Huang et al., 2004) were less biocompatible than low molecular weight chitosans (10 kDa) (Huang et al., 2004; Lavertu et al., 2006; Nimesh et al., 2010; Richardson et al., 1999).

For siRNA delivery we chose the $28 \mathrm{kDa}$ polymer - EAGC29, as others have reported that siRNA complexation is promoted by a higher molecular weight and higher charge density (Liu 
et al., 2007; Wagner, 2011). Additionally EAGC29 produced DNA complexes that were most stable to challenge by an endogenous polyanion - heparin (Figure $6 \mathrm{a}-\mathrm{c}$ ) and challenge by deoxyribonuclease (Figure 7a - c). Incidentally EAGC29, siRNA polyplexes were indeed less stable than EAGC29, DNA polyplexes when incubated with heparin (Figure $6 c$ and d) or deoxyribonuclease (Figure $7 \mathrm{c}$ and $\mathrm{d}$ ). However transfection competent siRNA polyplexes were produced with EAGC29 (Figure 11).

One notable drawback of these polymers is the need for really high levels of polymer in the formulation. For example the generation 2 diaminobutane dendrimer are transfection competent at a dendrimer, DNA weight ratio of 5: 1 (Dufes et al., 2005; Zinselmeyer et al., 2002) whereas transfection competence peaks with EAGC29 and EAGC21 at a polymer, DNA weight ratio of 30: 1 (Figure 9). However when considering the comparable IC50 values of EAGC21, EAGC29 (Table 1) and the Generation 2 diaminobutane dendrimer ${ }^{69}$, i.e. 0.828 , 0.522 and $0.030 \mathrm{mg} \mathrm{mL}^{-1}$ respectively, the new EAGC polymers still preserve their comparative biocompatibility advantage, as the delivery of $1 \mathrm{mg}$ of DNA would require $30 \mathrm{mg}$ of EAGC21 (3.6\% of the IC50), $30 \mathrm{mg}$ of EAGC29 (5.7\% of the IC50) and $5 \mathrm{mg}$ of the Generation 2 diaminobutane dendrimer (16.7\% of the IC50).

The in vivo administration of nucleic acids to the brain is limited by the blood brain barrier and the intranasal route of administration is a non-invasive method of bypassing the blood brain barrier (Chapman et al., 2013; Uchegbu et al., 2014b). These low cytotoxicity polymers that are able to complex and transfer nucleic acids into living cells were also able to locate siRNA within the olfactory bulb neurons 5 minutes after intranasal administration (Figure 12). This data provides a platform for the development of biocompatible nose to brain gene and RNA therapeutics and further proves the hypothesis that a critical level of alkylamine moieties on a polymer is able to yield a polymer with low cytotoxicity but sufficient gene transfer ability. 


\section{Conclusion}

In conclusion, we have prepared new chitosan derivatives that are orders of magnitude less cytotoxic than the commercial in vitro transfection reagents and clinical stage polymers and yet are able to transfer a variety of nucleic acids into cells to achieve either protein expression or gene silencing that is comparable to that achieved by the commercial reagent Lipofectamine 2000 or JetPEI. The relatively low cytotoxicity of these new polymers is crucial in that this will allow developers to produce nose to brain nucleic acid therapies for neurological indications. An important finding from our work is that it is crucial to limit the level of tertiary amines in a polymer nucleic acid vector, as tertiary amines are strong drivers of cell cytotoxicity.

\section{Acknowledgements}

Funding is acknowledged from the following organisations: University College London and Nanomerics Ltd. 


\section{Bibliography}

Abdelhady, H.G., Allen, S., Davies, M.c., Roberts, C.J., tendler, S.J.B., Williams, P.M., 2003. Direct real-time molecular scale visualisation of the degradation of condensed DNA complexes exposed to DNase I. Nucleic Acids Research 31, 4001-4005.

Akinc, A., Langer, R., 2002. Measuring the $\mathrm{pH}$ environment of DNA delivered using nonviral vectors: Implications for lysosomal trafficking. Biotechnol. Bioeng. 78, 503-508.

Alameh, M., Dejesus, D., Jean, M., Darras, V., Thibault, M., Lavertu, M., Buschmann, M.D., Merzouki, A., 2012. Low molecular weight chitosan nanoparticulate system at low N:P ratio for nontoxic polynucleotide delivery. International journal of nanomedicine 7, 1399-1414.

Alves, N.M., Mano, J.F., 2008. Chitosan derivatives obtained by chemical modifications for biomedical and environmental applications. International Journal of Biological Macromolecules 43, 401-414.

Benjaminsen, R.V., Mattebjerg, M.A., Henriksen, J.R., Moghimi, S.M., Andresen, T.L., 2013. The possible "proton sponge " effect of polyethylenimine (PEI) does not include change in lysosomal $\mathrm{pH}$. Mol Ther 21, 149-157.

Boussif, O., Lezoualc'h, F., Zanta, M.A., Mergny, M.D., Scherman, D., Demeneix, B., Behr, J.P., 1995. A versatile vector for gene and oligonucleotide transfer into cells in culture and in vivo: polyethylenimine. Proc. Natl. Acad. Sci. U. S. A. 92, 7297-7301.

Brownlie, A., Uchegbu, I.F., Schatzlein, A.G., 2004. PEl-based vesicle-polymer hybrid gene delivery system with improved biocompatibility. Int. J. Pharm. 274, 41-52.

Chapman, C.D., Frey, W.H., 2nd, Craft, S., Danielyan, L., Hallschmid, M., Schioth, H.B., Benedict, C., 2013. Intranasal treatment of central nervous system dysfunction in humans. Pharm. Res. 30, 2475-2484.

Charlton, S.T., Davis, S.S., Illum, L., 2007. Nasal administration of an angiotensin antagonist in the rat model: effect of bioadhesive formulations on the distribution of drugs to the systemic and central nervous systems. Int J Pharm 338, 94-103.

Cheng, W.P., Gray, A.I., Tetley, L., Hang, T.L.B., Schatzlein, A.G., Uchegbu, I.F., 2006. Polyelectrolyte nanoparticles with high drug loading enhance the oral uptake of hydrophobic compounds. Biomacromolecules 7, 1509-1520.

Chooi, K.W., Simao Carlos, M.I., Soundararajan, R., Gaisford, S., Arifin, N., Schatzlein, A.G., Uchegbu, I.F., 2014. Physical characterisation and long-term stability studies on quaternary ammonium palmitoyl glycol chitosan (GCPQ)--a new drug delivery polymer. J Pharm Sci 103, 2296-2306.

Clayden, J., Greeves, N., Warren, S., Wothers, P., 2001. Organic Chemistry. Oxford. Couzin-Frankel, J., 2009. Genetics. The promise of a cure: 20 years and counting. Science 324, $1504-1507$.

de la Fuente, M., Jones, M.C., Santander-Ortega, M.J., Mirenska, A., Marimuthu, P., Uchegbu, I., Schatzlein, A., 2015. A nano-enabled cancer-specific ITCH RNAi chemotherapy booster for pancreatic cancer. Nanomedicine 11, 369-377.

Delgado, D., del Pozo-Rodríguez, A., Solinís, M.A., Bartkowiak, A., Rodríguez-Gascón, A., 2013. New gene delivery system based on oligochitosan and solid lipid nanoparticles: 'in vitro' and 'in vivo' evaluation. European journal of pharmaceutical sciences : official journal of the European Federation for Pharmaceutical Sciences 50, 484-491.

Dufes, C., Keith, W.N., Bilsland, A., Proutski, I., Uchegbu, J.F., Schatzlein, A.G., 2005. Synthetic anticancer gene medicine exploits intrinsic antitumor activity of cationic vector to cure established tumors. Cancer Res. 65, 8079-8084.

Erbacher, P., Roche, A.C., Monsigny, M., Midoux, P., 1996. Putative role of chloroquine in gene transfer into a human hepatoma cell line by DNA/lactosylated polylysine complexes. Exp Cell Res 225, 186-194.

Erbacher, P., Zou, S., Bettinger, T., Steffan, A.-M., Remy, J.-S., 1998. Chitosan-Based Vector/DNA Complexes for Gene Delivery: Biophysical Characteristics and Transfection Ability. Pharmaceutical Research 15, 1332-1339. 
Garrett, N.L., Lalatsa, A., Uchegbu, I., Schatzlein, A., Moger, J., 2012. Exploring uptake mechanisms of oral nanomedicines using multimodal nonlinear optical microscopy. $J$ Biophotonics 5, 458-468.

Gaudet, D., de Wal, J., Tremblay, K., Dery, S., van Deventer, S., Freidig, A., Brisson, D., Methot, J., 2010. Review of the clinical development of alipogene tiparvovec gene therapy for lipoprotein lipase deficiency. Atheroscler Suppl 11, 55-60.

Gofrit, O.N., Benjamin, S., Halachmi, S., Leibovitch, I., Dotan, Z., Lamm, D.L., Ehrlich, N., Yutkin, V., Ben-Am, M., Hochberg, A., 2014. DNA based therapy with diphtheria toxin-A BC819: a phase $2 \mathrm{~b}$ marker lesion trial in patients with intermediate risk nonmuscle invasive bladder cancer. J Urol 191, 1697-1702.

Guo, X., Huang, L., 2012. Recent advances in nonviral vectors for gene delivery. Acc Chem Res 45, 971-979.

Hoggard-Koping, M., Tubulekas, I., Guan, H., Edwards, K., Nilsson, M., Varum, K., Artursson, P., 2001. Chitosan as a nonviral gene delivery system. Structure-property relationships and characteristics compared with polyethylenimine in vitro and after lung administration in vivo. Gene Therapy 8, 1108-1121.

Holzerny, P., Ajdini, B., Heusermann, W., Bruno, K., Schuleit, M., Meinel, L., Keller, M., 2012. Biophysical properties of chitosan/siRNA polyplexes: profiling the polymer/siRNA interactions and bioactivity. Journal of controlled release : official journal of the Controlled Release Society 157, 297-304.

Huang, M., Fong, C.-W., Khor, E., Lim, L.-Y., 2005. Transfection efficiency of chitosan vectors: Effect of polymer molecular weight and degree of deacetylation. Journal of Controlled Release 106, 391-406.

Huang, M., Khor, E., Lim, L.-Y., 2004. Uptake and Cytotoxicity of Chitosan Molecules and Nanoparticles: Effects of Molecular Weight and Degree of Deacetylation. Pharmaceutical Research 21, 344-353.

Hyde, S.C., Southern, K.W., Gileadi, U., Fitzjohn, E.M., Mofford, K.A., Waddell, B.E., Gooi, H.C., Goddard, C.A., Hannavy, K., Smyth, S.E., Egan, J.J., Sorgi, F.L., Huang, L., Cuthbert, A.W., Evans, M.J., Colledge, W.H., Higgins, C.F., Webb, A.K., Gill, D.R., 2000. Repeat administration of DNA/liposomes to the nasal epithelium of patients with cystic fibrosis. Gene Ther 7, 1156-1165.

lemsam-Arng, J., Kong, X., Schätzlein, A.G., Uchegbu, I.F., 2014. Star Shaped Poly(ethylene glycols) Yield Biocompatible Gene Delivery Systems. Pharmaceutical Nanotechnology 2, 182195.

Ishii, T., Okahata, Y., Sato, T., 2001. Mechanism of cell transfection with plasmid/chitosan complexes. Biochimica et Biophysica Acta 1514, 51-64.

Jorgensen, J.A., Hovig, E., Boe, S.L., 2012. Potent gene silencing in vitro at physiological pH using chitosan polymers. Nucleic acid therapeutics 22, 96-102.

Kafil, V., Omidi, Y., 2011. Cytotoxic impacts of linear and branched polyethylenimine nanostructures in a431 cells. Bioimpacts 1, 23-30.

Kean, T., Thanou, M., 2010. Biodegradation, biodistribution and toxicity of chitosan. Adv Drug Deliv Rev 62, 3-11.

Kim, I.D., Shin, J.H., Kim, S.W., Choi, S., Ahn, J., Han, P.L., Park, J.S., Lee, J.K., 2012. Intranasal delivery of HMGB1 siRNA confers target gene knockdown and robust neuroprotection in the postischemic brain. Molecular therapy : the journal of the American Society of Gene Therapy 20, 829-839.

Kim, T.H., Ihm, J.E., Choi, Y.J., Nah, J.W., Cho, C.S., 2003. Efficient gene delivery by urocanic acid-modified chitosan. Journal of Controlled Release 93, 389-402.

Lalatsa, A., Schätzlein, A.G., Uchegbu, I.F., 2011. Drug delivery across the blood brain barrier, in: MurrayMoo-Young, M., Butler, M., Webb, C., Moreira, A., Grodzinski, B., Cui, Z. (Eds.), Comprehensive Biotechnology 2nd edition. Elsevier, Amsterdam, pp. 657-668.

Lavertu, M., Méthot, S., Tran-Khanh, N., Buschmann, M.D., 2006. High efficiency gene transfer using chitosan/DNA nanoparticles with specific combinations of molecular weight and degree of deacetylation. Biomaterials 27, 4815-4824. 
Ledley, F.D., McNamee, L.M., Uzdil, V., Morgan, I.W., 2014. Why commercialization of gene therapy stalled; examining the life cycles of gene therapy technologies. Gene Ther 21, 188194.

Lee, M., Nah, J.-W., Kwon, Y., Koh, J.J., Ko, K.S., Kin, S.W., 2001. Water-Soluble and Low Molecular Weight Chitosan-Based Plasmid DNA Delivery. Pharmaceutical Research 18, 427431.

Leong, K.W., Mao, H.Q., Truong-Le, V.L., K.Roy, Walsh, S.M., August, J.T., 1998. DNApolycation nanospheres as non-viral gene delivery vehicles. Journal of Controlled Release 53, 183-193.

Liang, W., Lam, J.K.W., 2012. Endosomal Escape Pathways for Non-Viral Nucleic Acid Delivery Systems in: Ceresa, B. (Ed.), Molecular Regulation of Endocytosis.

Lin, C., Blaauboer, C.-J., Timoneda, M.M., Martin C, L., Steenbergen, M.v., Hennink, W.E., Zhong, Z., Feijen, J., Engbersen, J.F.J., 2008. Bioreducible poly(amido amine)s with oligoamin side chains: Synthesis, characterization, and structural effects on gene delivery. Journal of Controlled Release 126, 166-174.

Liu, X., Howard, K.A., Dong, M., Andersen, M.O., Rahbek, U.L., Johnsen, M.G., Hansen, O.C., Besenbacher, F., Kjems, J., 2007. The influence of polymeric properties on chitosan/siRNA nanoparticle formulation and gene silencing. Biomaterials 28, 1280-1288.

Lu, B., Wang, C.-F., Wu, D.-Q., Li, C., Zhang, X.-Z., Zhuo, R.-X., 2009. Chitosan based oligoamine polymers: Synthesis, characterization and gene delivery. Journal of Controlled Release 137, 54-62.

MacLaughlin, F.C., Mumper, R.J., Wang, J., Tagliaferri, J.M., Gill, I., Hinchcliffe, M., Rollanda, A.P., 1998. Chitosan and depolymerized chitosan oligomers as condensing carriers for in vivo plasmid delivery. Journal of Controlled Release 56, 259-272.

Malik, N., Wiwattanapatapee, R., Klopsch, R., Lorenz, K., Frey, H., Weener, J.W., Meijer, E.W., Paulus, W., Duncan, R., 2000. Dendrimers: Relationship between structure and biocompatibility in vitro, and preliminary studies on the biodistribution of I- 125-labelled polyamidoamine dendrimers in vivo. J. Control. Rel. 65, 133-148.

Mao, H.-Q., Roy, K., Troung-Le, V.L., Janes, K.A., Lin, K.Y., Wang, Y., August, J.T., Leong, K.W., 2001. Chitosan-DNA nanoparticles as gene carriers: synthesis, characterization and transfection efficiency. Journal of Controlled Release 70, 399-421.

Melino, G., Gallagher, E., Aqeilan, R.I., Knight, R., Peschiaroli, A., Rossi, M., Scialpi, F., Malatesta, M., Zocchi, L., Browne, G., Ciechanover, A., Bernassola, F., 2008. Itch: a HECTtype E3 ligase regulating immunity, skin and cancer. Cell Death Differ 15, 1103-1112.

Miller, N., 2012. Glybera and the future of gene therapy in the European Union. Nat Rev Drug Discov 11, 419.

Moreira, C., Oliveira, H., Pires, L.R., Simoes, S., Barbosa, M.A., Pego, A.P., 2009. Improving chitosan-mediated gene transfer by the introduction of intracellular buffering moieties into the chitosan backbone. Acta biomaterialia 5, 2995-3006.

Murphy, R.F., Powers, S., Cantor, C.R., 1984. Endosome pH measured in single cells by dual fluorescence flow cytometry: rapid acidification of insulin to $\mathrm{pH} 6$. The Journal of cell biology 98, 1757-1762.

Nimesh, S., Thibault, M.M., Lavertu, M., Buschmann, M.D., 2010. Enhanced gene delivery mediated by low molecular weight chitosan/DNA complexes: effect of $\mathrm{pH}$ and serum. Mol Biotechnol 46, 182-196.

Peng, Z., 2005. Current status of Gendicine in China: Recombinant Ad-p53 agent for treatment of cancers. Hum. Gene Ther. 16, 1016-1027.

Perez, A.P., Mundina-Weilenmann, C., Romero, E.L., Morilla, M.J., 2012. Increased brain radioactivity by intranasal $P$-labeled siRNA dendriplexes within in situ-forming mucoadhesive gels. International journal of nanomedicine 7, 1373-1385.

Piest, M., Engbersen, J.F.J., 2010. Effects of charge density and hydrophobity of poly(amido amine)s for non-viral gene delivery. Journal of Controlled Release 148, 83-90.

Pushpendra, S., Arvind, P., Anil, B., 2012. Nucleic Acids as Therapeutics, in: Erdmann, V.A., Barciszewski, J. (Eds.), From Nucleic Acids Sequences to Molecular Medicine. SpringerVerlag, Berlin, pp. 19-45. 
Renner, D.B., II, W.H.F., Hanson, L.R., 2012. Intranasal delivery of siRNA to the olfactory bulbs of mice via the olfactory nerve pathway. Neuroscience letters 513, 193-197.

Richardson, S.C.W., Kolbe, H.V.J., Duncan, R., 1999. Potential of low molecular mass chitosan as a DNA delivery system: biocompatibility, body distribution and ability to complex and protect DNA. International Journal of Pharmaceutics 178, 231-243.

Rungsardthong, U., Ehtezazi, T., Bailey, L., Armes, S.P., Garnett, M.C., Stolnik, S., 2003. Effect of Polymer lonization on the Interaction with DNA in Nonviral Gene Delivery Systems. Biomacromolecules. 4, 683-690.

Sato, T., Ishii, T., Okahata, Y., 2001. In vitro gene delivery mediated by chitosan. Effect of $\mathrm{pH}$, serum, and molecular mass of chitosan on the transfection efficiency. Biomaterials 22, 20752080.

Scholz, C., Wagner, E., 2012. Therapeutic plasmid DNA versus siRNA delivery: common and different tasks for synthetic carriers. Journal of controlled release : official journal of the Controlled Release Society 161, 554-565.

Siew, A., Le, H., Thiovolet, M., Gellert, P., Schatzlein, A., Uchegbu, I., 2012. Enhanced oral absorption of hydrophobic and hydrophilic drugs using quaternary ammonium palmitoyl glycol chitosan nanoparticles. Molecular Pharmaceutics 9, 14-28.

Solomons, T.W.G., Fryhle, C.B., 2011. Organic Chemistry. John Wiley \& Sons, Inc.

Strand, S.P., Lelu, S., Reitan, N.K., de Lange Davies, C., Artursson, P., Varum, K.M., 2010. Molecular design of chitosan gene delivery systems with an optimized balance between polyplex stability and polyplex unpacking. Biomaterials 31, 975-987.

Sykes, P., 1986. A Guidebook to Mechanism in Organic Chemistry, 6th Edition ed. Longman Scientific \& Technical, Essex.

Techaarpornkul, S., Wongkupasert, S., Opanasopit, P., Apirakaramwong, A., Nunthanid, J., Ruktanonchai, U., 2010. Chitosan-mediated siRNA delivery in vitro: effect of polymer molecular weight, concentration and salt forms. AAPS PharmSciTech 11, 64-72.

Thanou, M., Florea, B.I., Geldof, M., Junginger, H.E., Borchard, G., 2002. Quaternized chitosan oligomers as novel gene delivery vectors in epithelial cell lines. Biomaterials 23, 153159.

Tripathi, S.K., Goyal, R., Kumar, P., Gupta, K.C., 2012. Linear polyethylenimine-graft-chitosan copolymers as efficient DNA/siRNA delivery vectors in vitro and in vivo. Nanomedicine: nanotechnology, Biology, and Medicine 8, 337-345.

Uchegbu, I.F., Carlos, M., McKay, C., Hou, X.L., Schatzlein, A.G., 2014a. Chitosan amphiphiles provide new drug delivery opportunities. Polymer International 63, 1145-1153.

Uchegbu, I.F., Jones, M.C., Corrente, F., Godfrey, L., Laghezza, D., Carafa, M., Holm, P., Schätzlein, A.G., 2014b. The Oral and Intranasal Delivery of Propofol Using Chitosan Amphiphile

Nanoparticles. Pharmaceutical Nanotechnology 2, 65-74.

Uchegbu, I.F., Sadiq, L., Pardakhty, A., El-Hammadi, M., Gray, A.I., Tetley, L., Wang, W., Zinselmeyer, B.H., Schatzlein, A.G., 2004. Gene transfer with three amphiphilic glycol chitosans - the degree of polymerisation is the main controller of transfection efficiency. J. Drug Target. 12, 527-539.

Wagner, E., 2011. Polymers for siRNA Delivery: Inspired by Viruses to be targeted, Dynamic, and Precise. Accounts of Chemical research 45, 1005-1013.

Wang, D., Narang, A.S., Kotb, M., Gaber, O., Miller, D.D., Kim, S.W., Mahato, R.I., 2002. Novel Branched Poly(Ethylenimine)-Cholesterol Water-Soluble Lipopolymers for Gene Delivery. Biomacromolecules. 3, 1197-1207.

Wang, Q.Z., Chen, X.G., Liu, N., Wang, S.H., Liu, C.S., Meng, X.H., Liu, C.G., 2006. Protonation constants of chitosan with different molecular weight and degree of deacetylation. Carbohydr. Polymer 65, 194-201.

Wang, W., McConaghy, A.M., Tetley, L., Uchegbu, I.F., 2001. Controls on polymer molecular weight may be used to control the size of palmitoyl glycol chitosan polymeric vesicles. Langmuir 17, 631-636. 
Wiethoff, C.M., Middaugh, C.R., 2002. Barriers to Nonviral Gene Delivery. Journal of Oharmaceutical Sciences 92, 203-217.

Wong, K., Sun, G., Zhang, X., Dai, H., Liu, Y., He, C., Leong, K.W., 2006. Pei-g-chitosan, a Novel Gene Delivery System with Transfection Efficiency Comparable to Polyethylenimine in Vitro and after Liver Administration in Vivo. Bioconjugate Chem. 17, 152-158.

Zinselmeyer, B.H., Mackay, S.P., Schatzlein, A.G., Uchegbu, I.F., 2002. The lower-generation polypropylenimine dendrimers are effective gene-transfer agents. Pharm. Res. 19, 960-967. 


\section{Figure Captions}

1. $N, N$-di-(2'-ethylamine)- $N$-(2'-ethylamine)- $N$-acetyl-6-O-glycolchitosan (EAGC).

2. Titration curves of, GC17, EAGC11, EAGC17, EAGC21, EAGC22 and EAGC29. A polymer solution $\left(2 \mathrm{mg} \mathrm{mL}^{-1}\right.$ adjusted to $\mathrm{pH} 2$ with $\left.0.1 \mathrm{M} \mathrm{HCl}\right)$ was titrated with $\mathrm{NaOH}$ $(0.05 \mathrm{M})$.

3. Agarose gel electrophoresis of GC, EAGC17, EAGC21 and EAGC29 complexed with plasmid DNA $(a-h)$, EAGC29 complexed with siRNA ( $i$ and $j)$ in dextrose $5 \%$ and EAGC11 complexed with mRNA $(k)$ in phosphate buffer $(2 \mathrm{~mm}, \mathrm{pH}=6.0)$. Naked DNA/ siRNA/ mRNA lanes are labelled in red, while the polyplexes are labelled in green. EAGC polyplexes were prepared at various polymer, nucleic acid weight ratios (1: 1 to $70: 1$, green lane markers).

4. TEM micrographs of a) naked plasmid DNA, b) EAGC17, c) EAGC21, d) EAGC29, DNA nanoparticles at a polymer, DNA weight ratio of 10. e) Naked siRNA, f)EAGC29, siRNA nanoparticles at a polymer, siRNA weight ratio of 10 .

5 a) Mean particle size \pm sem of EAGC17, EAGC21 and EAGC29 DNA complexes ${ }^{* * *}=$ statistically significant difference between EAGC17 complexes and all other polymer complexes $(p \leq 0.001)$, \#\# = statistically significantly different between EAGC29 complexes and all other complexes $(p \leq 0.001)$. b) Mean particle size \pm sem of EAGC29, siRNA complexes,${ }^{* \star *}=$ statistically significant difference between EAGC, siRNA (5: 1) complexes and all other complexes $(p \leq 0.001)$. c) Mean zeta potential \pm sem of EAGC17, EAGC21 and EAGC29, DNA complexes used to generate data shown in Figure 5a, ${ }^{* *}=$ statistically significant difference between EAGC29, DNA (60: 1 weight ratio) complex and all other polymer, DNA complexes ( $p \leq 0.001)$. d) Mean zeta potential \pm sem of EAGC29, siRNA complexes used to generate data shown in Figure $5 b$. e) Mean particle size \pm SEM of EAGC11, mRNA complexes . f) Mean zeta potential \pm SEM of EAGC11, mRNA complexes. Statistical significance between respective formulations in $\mathbf{e}$ ) and $\mathbf{f}$ ) is indicated as follows: ${ }^{*} p \leq 0.05,{ }^{* *} p \leq 0.001$.

6. Agarose gel electrophoresis data from EAGC, DNA complexes at various polymer, DNA weight ratios (5: 1, 10:1, 30: 1 and 60: 1, green lane markers) after incubation with heparin [0.1 mg.mL $\mathrm{mL}^{-1}$ (left panels) and $1 \mathrm{mg} \cdot \mathrm{mL}^{-1}$ (right panels)] for 15min. a) EAGC17, DNA complexes, b) EAGC21, DNA complexes, c) EAGC29, DNA complexes, d) Agarose gel electrophoresis data from EAGC29, siRNA complexes at various polymer, siRNA weight 
ratios (5: 1, 10: 1, 30: 1 and 60: 1, green lane markers) after incubation with heparin [0.1 $\mathrm{mg} \cdot \mathrm{mL}^{-1}$ (left panels) and $1 \mathrm{mg} \cdot \mathrm{mL}^{-1}$ (right panels)] for $15 \mathrm{~min}$.

7. Agarose gel electrophoresis data from a) EAGC17, b) EAGC21 and c) EAGC29 polyplexes at various polymer, DNA weight ratios (5: 1, 10: 1, 30: 1 and 60: 1, green lane markers) after incubation with deoxyribonuclease $\left(1\right.$ unit $\left.\mu \mathrm{L}^{-1}\right)$ for $15 \mathrm{~min}$. Samples were as follows: $\mathrm{i}=\mathrm{EAGC}$, DNA complexes, $\mathrm{ii}=\mathrm{EAGC}$, DNA complexes + deoxyribonuclease, $\mathrm{iii}=\mathrm{EAGC}$, DNA complexes + deoxyribonuclease + heparin $\left(2 \mathrm{mg} \mathrm{mL}^{-1}\right)$. d) Agarose gel electrophoresis data from EAGC29, siRNA polyplexes at various polymer, siRNA weight ratios (5: 1, 10: 1, 30: 1 and 60: 1, green lane markers) after incubation with deoxyribonuclease $\left(1\right.$ unit $\left.\mu \mathrm{L}^{-1}\right)$ for $15 \mathrm{~min}$. Samples were as follows: $\mathrm{i}=\mathrm{EAGC29}$, siRNA complexes, $\mathrm{ii}=\mathrm{EAGC}$, siRNA complexes + ribonuclease (RNAse) + heparin $\left(2 \mathrm{mg} \mathrm{mL}^{-1}\right)$.

8. Cell cytotoxicity of the EAGC polymers and the commercial in vitro transfection agent, Lipofectamine 2000 in the A431 cell line, cells were incubated for 6h with EAGC17, EAGC21, EAGC29 and Lipofectamine, and for 4h with EAGC11 and EAGC22 and the data are expressed as the mean \pm SEM of three separate experiments. b) IC50 in the A431 cell line as a function of ethylamine substitution. Equation of the line: IC50 $=6.18$ $D S_{\text {tert }}^{-0.90} \quad\left(r^{2}=0.9991\right)$, where $D S_{\text {tert }}=$ degree of tertiary amine substitution $($ mole $\%$ per monomer)

9a) $\beta$-Galactosidase gene expression (mean \pm SEM), following the administration of polyplexes prepared from EAGC17 [\#\# = significantly different from all other EAGC17 polyplexes in panel a $(p \leq 0.001)]$, b) EAGC21 and c) EAGC29 $\left[{ }^{\#}=\right.$ significantly different from EAGC29, DNA (60: 1) polyplex $(p \leq 0.05)$, \#\# = significantly different from EAGC29, DNA (60: 1) polyplex ( $\leq 0.001)$ ]. Lipofectamine lipoplexes were dosed at a concentration of $0.1 \mu \mathrm{g}$ DNA, ${ }^{* * *}=$ significantly different from Lipofectamine $(p \leq 0.001)$. d) Comparison of the transfection efficacy between EAGC17, EAGC21 and EAGC29, ${ }^{* * *}=$ significantly different from EAGC17 polyplexes $(p \leq 0.001)$, \#\# = significantly different from Lipofectamine 2000 ( $p \leq 0.001$ ). All protein expression data with the EAGC polymers (polymer, DNA weight ratio > 1) and Lipofectamine 2000 were significantly different from the protein expression shown with DNA alone. Numbers on the X-axis denote the polymer, DNA weight ratio.

9e) Effect of the presence of chloroquine $(100 \mu \mathrm{M})$ on $\beta$-Galactosidase gene expression (mean \pm sem) in the $A 431$ cell line. ${ }^{* * *}=$ significantly different from formulations dosed in the presence of chloroquine $(p \leq 0.001),{ }^{\# \#}=$ EAGC21 polyplexes are significantly different 
from Lipofectamine formulations (both in the absence of chloroquine, $p \leq 0.001$ ). Numbers on the $\mathrm{x}$-axis denote the polymer, DNA weight ratios.

9f) Effect of the presence of proteins on $\beta$-Galactosidase gene expression (mean \pm sem) in the A431 cell line ${ }^{* * *}=$ significantly different from formulations dosed in the absence of proteins $(p \leq 0.001),{ }^{*}=$ significantly different from formulations dosed in the absence of

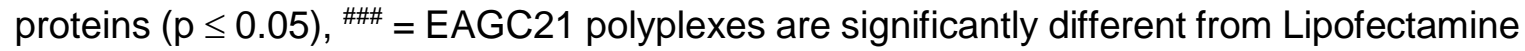
formulations (both in the presence of proteins, $p \leq 0.001$ ). Numbers on the $x$-axis denote the polymer, DNA weight ratios.

10. The quantification of $\beta$-Galactosidase protein expression in the A431 cell line, following the mRNA transfection. Numbers on the $x$-axis denote the polymer: mRNA weight ratios. Data are presented as mean \pm SEM. Statistical significance is indicated as follows: ${ }^{*} p$ $\leq 0.05,{ }^{* *} \mathrm{p} \leq 0.01$.

11. Western Blotting analysis of ITCH knockdown in A431 cells, Lane descriptors: A Molecular weight marker, B - Untreated Cells, C - Polymer alone, D - Naked ITCH siRNA, E - Naked Scrambled siRNA, F - Lipofectamine + ITCH siRNA, G - EAGC29, ITCH siRNA (polymer, siRNA weight ratio = 10), H - EAGC29, Scrambled siRNA (polymer, siRNA weight ratio = 10: 1), I - EAGC29, ITCH siRNA (polymer, siRNA weight ratio = 30: 1), J EAGC29, Scrambled siRNA (polymer, siRNA weight ratio = 30: 1), K - EAGC29, ITCH siRNA (polymer, siRNA weight ratio = 60: 1), L - EAGC29, Scrambled siRNA (polymer, siRNA weight ratio $=60: 1$ ).

12 a) Orthogonal view reconstructions of depth-stack images of an olfactory bulb sample (untreated group) using CARS (red - brain tissue). b) Orthogonal view reconstructions of depth-stack images of an olfactory bulb sample, harvested 5 min after nasal administration of naked siRNA $(15 \mu \mathrm{g}, 80 \mu \mathrm{L})$ using contrast from TPF (green - siRNA Alexa Fluor ${ }^{\circledR}$ Fluorescent) and CARS (red - brain tissue). c) Orthogonal view reconstructions of depthstack images of an olfactory bulb sample, harvested 5 min after nasal administration of EAGC29, siRNA nanoparticles with an EAGC29, siRNA weight ratio of 60: 1 using contrast from TPF (green - siRNA Alexa Fluor ${ }^{\circledR}$ Fluorescent) and CARS (red - brain tissue). 